\title{
Remittance inflows affect the ecological footprint in BICS countries: do technological innovation and financial development matter?
}

\author{
Bo Yang ${ }^{1} \cdot$ Atif Jahanger ${ }^{1} \cdot$ Minhaj Ali ${ }^{1}$ \\ Received: 23 November 2020 / Accepted: 5 January 2021 / Published online: 15 January 2021 \\ (C) The Author(s), under exclusive licence to Springer-Verlag GmbH, DE part of Springer Nature 2021
}

\begin{abstract}
This study examines the impact of remittance inflows, technological innovations, and financial development on environmental quality in Brazil, India, China, and South Africa (BICS) economies over 1990-2016. This study employed a comprehensive environment proxy, i.e., ecological footprint for environmental quality, and also considers more advanced and robust econometric (second-generation) techniques. The outcomes of the current study reveal that remittance inflows and financial development significantly deteriorate the environmental quality, while technological innovations are an essential factor for the reduction of ecological footprint level. Furthermore, the results of the interaction terms show a significantly adverse effect on the ecological footprint. Additionally, the findings of country-wise analysis reveal that remittance inflows and financial development worsen the environmental quality in each sample country, while the technological innovations promote the environmental sustainability that is steady with panel results. Besides, the environmental Kuznets curve (EKC) hypothesis was verified across the BICS economies. Consistent with the key findings, an inverted U-shaped relationship exists between economic growth and ecological footprint in the case of Brazil and South Africa. In contrast, the U-shaped EKC hypothesis exists in the case of China and India. For robust policy implication, the findings of this study highlighted the dire need for "green policy tools" that should be linked with the BICS economy policies and driver for sustained growth.
\end{abstract}

Keywords Ecological footprint $\cdot$ Remittance inflows $\cdot$ Technological innovations $\cdot$ Financial development $\cdot$ EKC hypothesis

\section{Introduction}

Since the 1950s, environmental pollution has become a crucial hazard and continued a hurdle on the way of sustainable development because it takes various environmental challenges including deforestation, climate change, global warming, and water wastes and shortages (Ulucak et al. 2019). The rising trend of greenhouse gases (GHGs) not only is a hazard to the health of the biophysical ecosystem but also has a reflective influence on human society. The researchers have studied and described the numerous determinants of environmental quality and indorse the sources that how to improve environmental quality worldwide. Among others, recently, the remittance

Responsible Editor: Nicholas Apergis

Atif Jahanger

atif_jahanger@hotmail.com

1 School of Economics, Zhongnan University of Economics and Law, Wuhan 430073, China inflows, technological innovations, and financial development have conceived major attention and an important determinant of environmental sustainability. Particularly, in the existing literature, the influence of remittance inflows, technological innovations, and financial development on carbon dioxide $\left(\mathrm{CO}_{2}\right.$ emissions) has been observed (Brown et al. 2020; Yang et al. 2020a; Chen and Lee (2020; Amin et al. 2020; Ibrahiem 2020). Although, previous studies have not found any definite conclusions, regarding the influence of specified variables on environmental quality.

In the existing literature regarding environmental quality, researchers have usually used $\mathrm{CO}_{2}$ emissions as a proxy of environmental performance. However, $\mathrm{CO}_{2}$ emissions as a proxy of environmental deprivation do not deliberate the resources, i.e., forest, fishing, oil, mining, and soil (Ulucak and Apergis 2018). In this circumstance, ecological footprint (EF) is widely known as a more inclusive indicator of environmental degradation (Dogan et al. 2020; Usman and Hammar 2020; Kirikkaleli et al. 2020; Ahmed et al. 2020). The EF is contained of six different kinds of areas such as forest land, fishing grounds, cropland, carbon footprint, grazing land and 
build-up land that describe the wide concept of environmental quality. Although, to the best of our knowledge, there is no evidence was found on the role of remittance inflows, technological innovation, and financial development on environmental sustainability in the context of BRICS (i.e., Brazil, Russia, India, China, and South Africa) economies. It is estimated for 2050 that China will become the 1st biggest economy in the world, India 3rd, Russia, and Brazil will categorize 4th and 5th respectively (Tian et al. 2020). The aggregate economic growth of BRICS countries is growing from approximately $17 \%$ in 1996 to $33 \%$ in $2018 .{ }^{1}$ The share of worldwide GHGs emissions in BRICS economies has $40 \%$ in 2018 (Tian et al. 2020). In the context of global carbonemitting countries, China is 1st largest world emitted economy (Lin et al. 2020), South Africa 14th largest economy that releases emissions in 2018, Brazil was 13th largest emitted economy in 2016, Russia rank is 5th in global carbon emitter (Su et al. 2020), and India has 3rd most significant share that polluted the environment quality (Bhattacharya 2020).

Technological innovation (TE) is one of the most authentic ways to reduce environmental degradation and also improve economic growth (Chen and Lee 2020; Yu and Du 2019; Brandão Santana et al. 2015; Zhou et al. 2016; Gerlagh 2007; Canadell et al. 2007; Sohag et al. 2015). The 12th BRICS summit was held on November 17, 2020, virtually meeting due to the coronavirus disease 2019 (COVID-19) pandemic and has done many agreements in the field of science, technology, and innovation sectors. ${ }^{2}$ High TE could lead to faster implementation of renewable energy to meet the energy demand and change the structure of energy utilization, i.e., the conventional energy source to clean energy source (Sohag et al. 2015). The COVID-19 pandemic has enhanced tentatively and burdens on organizations/firms and households universally. In BRICS countries like China have revealed these issues that can be overcome with strong investment in technological innovations. $^{3}$ The financial sector of China has supported the firms/ households for technological infrastructure during the COVID19 pandemic, and only China's economy has been growing around the world. Hence, TE enhances efficiency and promotes more sustainable and eco-friendly economic growth.

Currently, numerous studies have found that remittance inflows are another potential source that increases environmental degradation in various economies of the world. The remittance inflows have a vital source of foreign capital which significant positive influence on numerous economies outcomes for example financial development (Olayungbo and Quadri 2019), foreign direct investment (Basnet and Upadhyaya 2014), technological innovation (Tshikala et al. 2019), and economic growth (Chowdhury 2016), which are

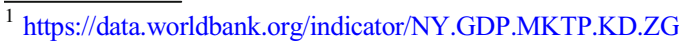

${ }^{2}$ For more details: https://infobrics.org/news/summits/

${ }^{3}$ IMF, World Economic Outlook: a long and difficult ascent, October 2020
}

measured as an important indicator for environmental sustainability. The BRICS countries have received a remittance of approximately $1.10 \$$ trillion in 2017 ; these economies have top remittance receiver's economies among developing countries. ${ }^{4}$ The remittance supports the financial sector that provides funds/loans to investors for eco-friendly technology (Yang et al. 2020a). The nexuses between remittance inflows and $\mathrm{CO}_{2}$ emissions have been investigated by a number of researchers (for example, Neog and Yadava 2020; Brown et al. 2020; Villanthenkodath and Mahalik 2020; Yang et al. 2020a; Rahman et al. 2019; Sharma et al. 2019). More specifically, there is no clear evidence on the role of remittance inflows, financial development, and technological innovation in influencing environmental sustainability by using ecological footprint in the context of BICS countries simultaneously. The environmental Kuznets curve (EKC) hypothesis suggests that the earlier stage of economic development displays a negative association between low economic growth per capita and environmental sustainability, but later, there is a positive association between a higher level of growth/GDP per capita and environmental sustainability (Grossman and Krueger 1991). The inverted U-shaped curve which EKC proposed is illustrated in Fig. 1.

Hence, it is imperious to study the dynamic linkage between remittance inflows, technological innovations, financial development, and ecological footprint in the case of BICS economies and help policymakers to make a more realistic and accurate picture of environmental quality strategies. On the given framework, the current paper makes numerous contributions to the environment literature. The existing literature has used $\mathrm{CO}_{2}$ emission as the proxy of environmental degradation, which is broadly criticized by many scholars for its imperfect nature (Neog and Yadava 2020; Brown et al. 2020; Villanthenkodat et al. 2020; Yang et al. 2020a; Rahman et al. 2019; Sharma et al. 2019). Firstly, to the best of the author's knowledge, this is the first study that used the ecological footprint (as a proxy of environmental sustainability) to investigate the dynamic linkage between remittance inflows, technological innovations, and financial development in the context of the EKC framework and given more valuable policy implications for BICS economies. Second, the current study also employed the moderation effect between remittance inflows and financial development, and remittance inflows and technological innovations on ecological footprint. Third, we introduce a new theoretical linkage in our model which will be able to explain the remittance inflows, technological innovation, financial development and ecological footprint nexus in the framework of the EKC hypothesis. Fourth, the current study has applied comparatively advanced econometric techniques (second-generation) for the empirical analysis.

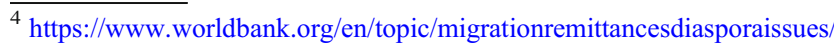
brief/migration-remittances-data
} 


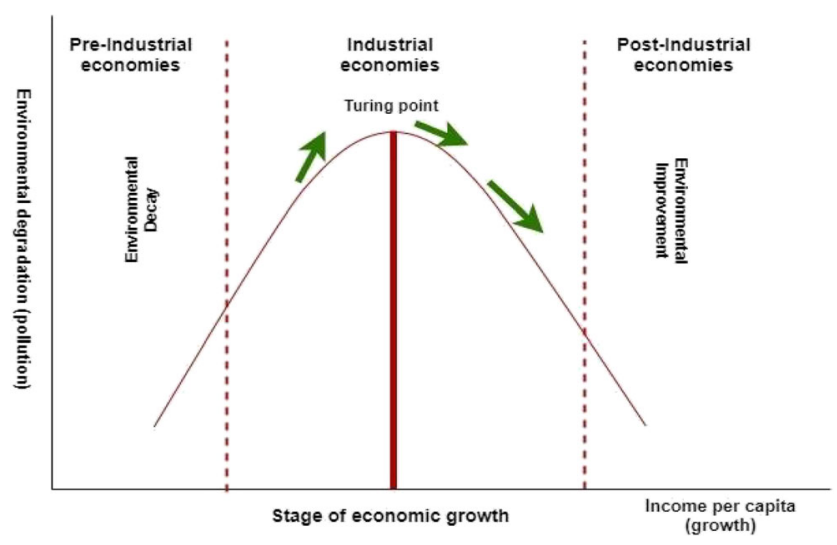

Fig. 1 Environmental Kuznets curve

We answer three questions in this current study. First, how remittance inflows, technological innovations, and financial development influence the ecological footprint for BICS economies? Second, whether the EKC hypothesis exists or not in BICS economies? Third, how the moderating role of financial development and technological innovations with remittance inflows influence the ecological footprint in the case of BICS economies? in order to answer these questions, this study employed the Dynamic Seemingly Unrelated Regression (DSUR) and Fully modified ordinary least square (FMOLS) techniques. We expect a positive and significant relationship running from remittance inflows and financial development to ecological footprint. Theoretically, technological innovation has a favorable effect on environmental quality. Furthermore, this linkage is categorized by a modified EKC hypothesis and an inverted U-shaped form. To answer the third question, we expect that the interaction terms have a negative influence on ecological footprint.

The rest of the study is organized as follows: the "Literature review" section expresses a brief review of the literature concerning the linkage between remittance inflows, technological innovation, financial development, economic growth, and environmental sustainability. The "Theoretical framework, data descriptions, and methodology" section presents the data presentation, model construction, and econometric strategy. The "Results and discussion" section provides the outcomes and their explanation, and finally, the conclusion and policy implications are deliberated in the "Conclusion and policy implication" section.

\section{Literature review}

The nexus between remittance inflows, technological innovation, financial development, and ecological footprint has been recognized in numerous empirical studies. The following sections have been divided into three sub-sections linking the nexus between remittance inflows, financial development, technological innovation, and environmental sustainability. The literature related to the influence of economic growth on environmental sustainability is also emphasized and providing mixed results (see Table 1)

\section{Remittance inflows and the environment}

Remittances play a vital role in accelerating economic growth (GDP) and are considered a key determinant of income for an economy (Meyer and Shera 2017; Glytsos 2005). Remittance has been identified as crucial for financial development, and an increase in the inflows of remittance creates a higher demand for financial institutes that may lead to an increase the environmental degradation. In the current literature, some scholars have investigated the influences of remittances inflows on environmental sustainability for different regions. Recently, Yang et al. (2020a) studied the influence of remittance inflows, energy utilization, and $\mathrm{CO}_{2}$ emission in 97 countries. They reported that remittances increased the $\mathrm{CO}_{2}$ emissions by enhancing the aggregate demand for industrial production with raise the energy utilization (fossil fuel) which in turn increases environmental degradation while globalization has a favorable effect on environmental quality. They argued that globalization brings green technologies development which boots the economic growth with the creation of minimum emission. Likewise, Rahman et al. (2019 have found a positive influence of remittance on the environment in the case of the Philippines, Sri Lanka, and Pakistan while, observed an insignificant effect in the case of India and China. They suggested that the government can do so by enhancing energy efficiency and replacing fossil fuels with renewable energy resources as well as monitoring financial development to reduce $\mathrm{CO}_{2}$ emissions.

Another massive study by Neog and Yadava (2020) examined the link between remittance and environmental sustainability during 1980-2014. Their finding revealed that negative shock of remittance enhances environmental degradation while adverse shocks of remittance had the ability to improve the environmental quality. Likewise, Khan et al. (2020) applied the common correlated effect mean group (CCEMG) to scrutinize the association between remittance inflows and environmental sustainability in BRICS economies from 1986 to 2016. Their outcome revealed that remittances enhanced environmental degradation in the case of BRICS countries. The reason is that BRICS countries are of the top remittances' receiver economies. Normally, remittance inflows enhance the aggregate demand for the production process which increases the energy consumption due to more demand for industrial goods that enhanced environmental degradation. Similar findings are reported by Brown et al. (2020) and Villanthenkodath et al. (2020). Furthermore, Wawrzyniak 
Table 1 Summary of existing studies of the EKC hypothesis using EF

\begin{tabular}{|c|c|c|c|c|}
\hline Author & Period & Country/region & Method & $\begin{array}{l}\text { Findings/ } \\
\text { EKC }\end{array}$ \\
\hline Pata (2020) & 1980-2016 & USA & FMOLS, DOLS & YES \\
\hline Usman et al. (2020a) & 1995-2017 & $\begin{array}{l}20 \text { highest emitting } \\
\text { countries }\end{array}$ & $\begin{array}{l}\text { AMG, PMG, } \\
\text { FMOLS }\end{array}$ & NO \\
\hline Mrabet et al. (2017) & $1980-2011$ & Qatar & ARDL & NO \\
\hline $\begin{array}{l}\text { Khoshnevis Yazdi and Ghorchi } \\
\text { Beygi (2018) }\end{array}$ & 1985-2016 & 25 Africa economies & PMG & YES \\
\hline Mahmood et al. (2020) & 1984-2016 & 21 economies & AMG & YES \\
\hline Al-Mulali et al. (2015) & 1980-2008 & 82 countries & GMM & YES \\
\hline Ozturk et al. (2016) & $1988-2008$ & 144 countries & GMM & Mixed \\
\hline Destek and Sarkodie (2019) & $1977-2013$ & 11 countries & AMG & YES \\
\hline Așici and Acar (2015) & 2004-2008 & 116 countries & FE regression & Mixed \\
\hline Hassan et al. (2019) & $1970-2014$ & Pakistan & ARDL & YES \\
\hline Liu et al. (2018) & $1990-2013$ & 3 Asia countries & ECM & Mixed \\
\hline Katircioglu et al. (2018) & 1995-2014 & 10 countries & $\mathrm{RE}$ regression & YES \\
\hline Dogan et al. (2019) & $1971-2013$ & MINT countries & ARDL & Mixed \\
\hline Kassouri and Altıntaș (2020) & $1990-2014$ & 14 European countries & D-CCE & NO \\
\hline Ozcan et al. (2018) & $1961-2013$ & Turkey & BRWC & NO \\
\hline Sharif et al. (2020) & 1995-2017 & Turkey & QARDL & YES \\
\hline Aziz et al. (2020) & $1990-2016$ & Pakistan & QARDL & YES \\
\hline Arshad et al. (2020) & $1991-2017$ & 5 Asia countries & FMOLS & Mixed \\
\hline Uddin et al. (2016) & 1961-2011 & 22 Countries & $\mathrm{ECM}$ & Mixed \\
\hline Așıcı and Acar (2018) & 2004-2010 & 87 countries & FE regression & NO \\
\hline Al-mulali et al. (2016) & 1980-2009 & 58 countries & GMM & NO \\
\hline Mikayilov et al. (2019) & 1996-2014 & Azerbaijan & TVC & $\mathrm{NO}$ \\
\hline
\end{tabular}

Abbreviations: $A R D L$ autoregressive distributed lag, $D O L S$ dynamic ordinary least square, FMOLS fully modified ordinary least square, $P M G$ pooled mean group, $A M G$ augmented mean group, $G M M$ generalized method of moments, $F E$ fixed effect, RE random effect, $Q A R D L$ quantile autoregressive distributed lag, $D-C C E$ dynamic common correlated effect estimator, $B R W C$ bootstrap rolling window causality, $T V C$ conventional cointegration approach and Doryń (2020) examined the link between remittance inflows and environmental performance. They found that remittance has an insignificant impact on environmental quality. On the other hand, Sharma et al. (2019) documented the negative influence of remittance on $\mathrm{CO}_{2}$ emission due to an insufficient supply of electricity to fulfill the demand of industries and a higher electricity tariff that instigated consumers to spend a significant amount of remittances on renewable energy. Qingquan et al. (2020) also found that remittance inflows undermine the environmental quality due to unfavorable environmental implications for less eco-friendly technologies and socially negligent consumption in Australia. Nevertheless, Usama et al. (2020) documented the negative association between remittance inflows and $\mathrm{CO}_{2}$ emissions in the case of Ethiopia. They observed that the negative influence of remittances on $\mathrm{CO}_{2}$ emission can be described on the basis that the impact of remittance might have pushed remittancereceiving families to move towards renewable energy electricity consumption. In sum, the given review of the literature shows that remittance has an adverse influence on environmental sustainability, and the literature still does not reach any consensus.

\section{Technological innovations and the environment}

Prior research demonstrates a significant impact of technological innovations on environmental sustainability. By using the different techniques, methods, and samples, previous literature on the association between technological innovation and the environment have yielded mixed results. In this sense, Usman and Hammar (2020) studied the impact of technological innovations on environmental sustainability in the case of Asia Pacific Economic Cooperation (APEC) countries and found that technological innovation significantly deteriorates the environmental quality. Furthermore, results explored that technologies associated with energy invention do not promote the grown growth. Kumail et al. (2020) inspected the nexus between 
technological innovations and environmental quality in the case of Pakistan from 1970 to 2017. Their empirical results indicated that technological innovations would enhance the environmental quality as upgraded technology could result in inefficient production and less utilization of energy, thus this will generate a smaller quantity of emissions. Similarly, Töbelmann and Wendler (2020) found an adverse impact of technological innovations on environmental degradation due to increases in the usage of renewable energy in the energymix structure and also improve environmental quality.

Many studies have explored the relationship between technological innovations and environmental degradation across the globe and found a negative influence on environmental degradation (Chen and Lee 2020; Yu and Du 2019; Brandão Santana et al. 2015; Zhou et al. 2016; Gerlagh 2007; Sagar and Holdren 2002; Canadell et al. 2007; Sohag et al. 2015; Kverndokk et al. 2004; Costantini et al. 2017; Ang 2009; Fei et al. 2014). Other studies explored that technological innovations may degrade the environmental quality due to a lack of research and development (R\&D) investment so the desired level of TE has not been attained so for Cheng et al. (2019), Gu and Wang (2018), Kivyiro and Arminen (2014), and Yongping 2011). In sum, the extant literature shows that the effect of technological innovation on environmental sustainability could be positive/negative. The aggregate influence of technological innovations on environmental sustainability could be elected as either positive/negative, based on the sample/period of countries.

\section{Financial development, urban population, and the environment}

Theoretically, scholars hold a contradictory point of view on the relationship between financial development and environmental quality. Some researchers, i.e., Tamazian and Rao (2010), Saidi and Mbarek (2017), Omri et al. (2015), Dogan and Turkekul (2016), Zaidi et al. (2019), Usman et al. (2020b), Zafar et al. (2019), Shahbaz et al. 2013 and Yang et al. (2020b), argued that financial inclusive could enhance the environmental quality by channelizing the investment level for eco-friendly/green technologies or transfer technology to developed countries through providing incentives/funds or subsidies to the investors. On contrary, Al-Mulali et al. (2015), Shahbaz et al. (2016), Bekhet et al. (2017), Yang et al. (2020a), Lu (2018), Cetin et al. (2018), and Gök (2020) argued that financial inclusive enhance the environmental degradation by providing funds at minimum interest/ cost to the individual investors that ultimately enhance the purchasing power parity of energy-intensive equipment, i.e., automobile and other equipment that result in degrading the environmental quality. The brief review of the relationship between financial development and environmental sustainability suggested that financial development might have a potential influence on environmental quality. This influence could be elected as either positive/negative, based on such links can demonstrate to be convincing in nature. This study has also explored the association between urban population and environmental sustainability (Mahmood et al. 2020; Wang et al. 2020; Wang et al. 2018).

\section{Theoretical framework, data descriptions, and methodology}

\section{Theoretical framework}

The determinant of environmental degradation is widely studied in the area of energy economics. Besides this indicator, GDP is the primary source of GHGs emissions. For example, higher GDP will require huge energy utilization for production activities. Ultimately, enhanced GDP causes polluted environmental quality. However, the influence of technological innovation and remittance on ecological footprints is not yet studying empirically in any economy like BICS countries. The theoretical framework shown in Fig. 2 explores the influences of technological innovation, financial development, and remittances on environmental sustainability. For instance, if any economy produces economic growth with the help of ecofriendly technologies, it will not only enhance the economic growth but also improve energy efficiency, as a result, improve environmental quality. Furthermore, remittance inflows increase the level of household income and raise the demand for goods that augments the production process (De and Ratha 2012). The rise in production activities leads to enhance demand for energy utilization (Irons and Irons 2019). The huge demand for energy usage could damage the environmental quality (Yang et al. 2020a). Many scholars believe that technological innovation can improve energy efficiency through Research and Development (R\&D) investment and thereby to a reduction in energy utilization whether it is for total energy utilization/fossil fuel (Wang et al. 2020; Jin et al. 2018). Such R\&D investment needed for the manufactures/Industries can be alleviated by the credit support of financial sectors in a national economy. Extending bank credit to eco-friendly technology can be subsidized by the growth of financial institutions. The growth of the financial system may be improved by inflows of remittance. Hence, this evidently shows that remittance inflow may reduce environmental degradation if remitted cash/money is financed in renewable energy/eco-friending technologies.

\section{Data, variable, and descriptive statistics}

The current study aims to explore the impact of remittance inflows, financial development, technological innovation, and ecological footprint in the BICS economies: Brazil, 
Fig. 2 The theoretical framework between remittance inflows and environment and the symbol indicate an increase. Source: Villanthenkodath et al. (2020) and Ahmad et al. (2019)

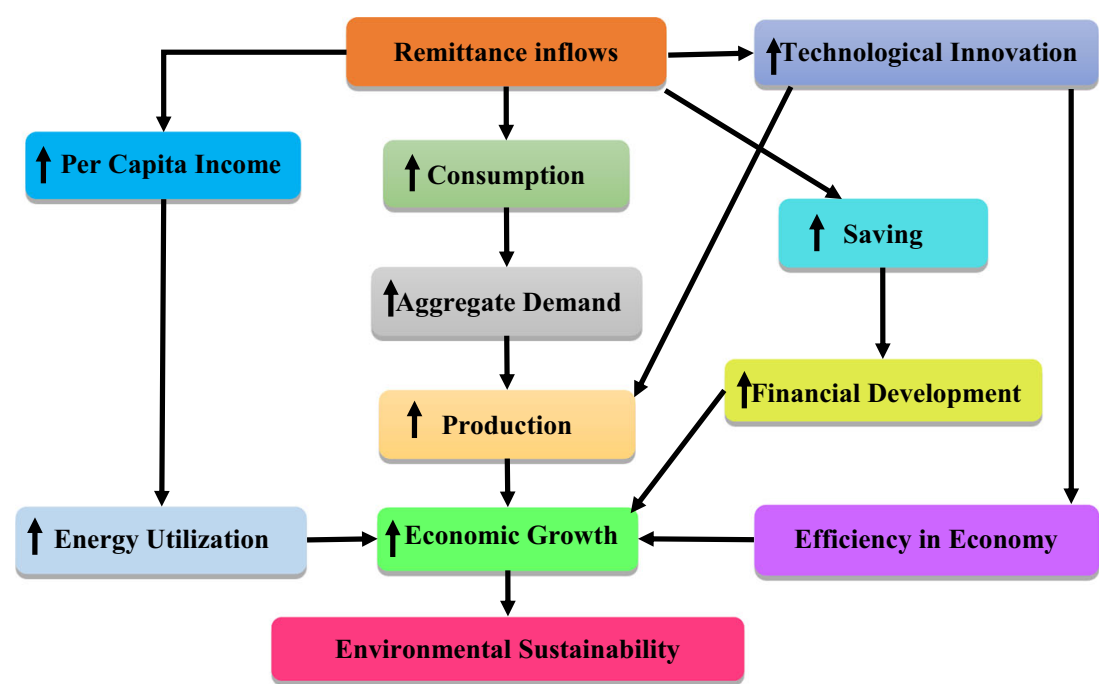

India, China and South Africa over the period from 1990 to 2016. Russia is not included in the sample due to the unavailability of data concerning financial development. The variable of ecological footprint (EF) is defined in an aggregate of six dimensions namely, i.e., carbon, build-up land, grazing land, fishing grounds, forest land, and cropland in terms of global hectares per capita. Remittance inflows (REM) is calculated total personal remittance inflows received in current US\$; financial development (FD) is measured by the domestic credit by the private sector is the percentage of GDP. The data of technological innovation (TE) is based on the number of the patent application field every year; GDP per capita (GDP) is estimated in constant 2010 US\$. The data of the urban population (URP) is taken from the percentage of the total population and energy consumption (ENG) is measured in kilograms of oil equivalent per capita. The data of GDP, ENG, REM, URP, and FD are attained from the website of the World Bank (https://data.worldbank.org/). The date of technological innovation is collected from the website of the World Intellectual Property Organization (https:/www3.wipo.int/ ipstats/), and data of ecological footprint is taken from the Global Footprint websites (https://www.footprintnetwork. org/resources/data/). Figure 3 illustrates that the BRICS and world countries discharging the EF drivers in percentage, which show the portion of $\mathrm{CO}_{2}$ emissions is $64 \%$ shadowed by cropland $17 \%$, forest product $9 \%$, grazing land $6 \%$, builtup land $2 \%$, and fishing ground also $2 \%$ by these BICS emitting economies. However, the world share of carbon emission $61 \%$ shadowed by cropland $19 \%$, forest product $10 \%$, and grazing land $5 \%$, and built-up land $2 \%$, and fishing ground $3 \%$. This suggests that these emitting BICS economies have produced more than $3 \% \mathrm{CO}_{2}$ emission as correlated to the world. The descriptive statistics and correlation matrixes are represented in Table 2 . The current study specifies the summary statistics of our variables from 1990 to 2016 through box plots (Fig. 4).

Table 2 presents the properties of the analyzed variables employed in the current study. The ecological footprint (LnEF) is significantly positively correlated with all the variables, i.e., LnREM, LnFD, LnGDP, LnTE, and LnURP except LnENG. On the other hand, high remittance inflows could improve the efficiency of financial sectors, GDP, energy utilization, and technological innovation through remitted money is invested in eco-friendly technologies with proper channels. A highly positive correlation (0.8322) is observed between financial development and technological innovation, while a highly negative correlation (0.8294) exists between remittance inflows and energy utilization. It is due to the fact that in most BICS countries, financial development is directly related to their technological innovation which enhances investment level in research and development projects. However, on the other hand, technological innovations are also enhancing the financial resources of the economy.

\section{Model construction}

The current study examined the influence of remittance inflows, technological innovation, and financial development on the ecological footprint in the case of BICS economies, specifically in line with Yang et al. (2020a), Neog and Yadava (2020), Mahmood et al. (2020), Chen and Lee (2020), Yu and Du (2019), Dogan et al. (2019), and Dogan and Seker (2016). For this intention, the panel version of the econometric model is expressed as follows:

$\mathrm{EF}_{\mathrm{it}}=\mathrm{A}_{0} \mathrm{REM}_{\mathrm{it}}^{\beta_{1 \mathrm{i}}} \mathrm{TE}_{\mathrm{it}}^{\beta_{2 \mathrm{i}}} \mathrm{FD}_{\mathrm{it}}^{\beta_{3 \mathrm{i}}} \operatorname{GDP}_{\mathrm{it}}^{\beta_{4 \mathrm{i}}} \mathrm{ENG}_{\mathrm{it}}^{\beta_{5 \mathrm{i}}} \operatorname{URP}_{\mathrm{it}}^{\beta_{6 \mathrm{i}}} \mu_{\mathrm{it}}(1)$

where EF indicates ecological footprint; TE denotes the technological innovation; FD shows financial development index; 
Table 2 Descriptive statistics and pair-wise correlation

\begin{tabular}{|c|c|c|c|c|c|c|c|}
\hline & $\mathrm{LnEF}$ & LnREM & LnFD & LnGDP & LnENG & LnTE & LnURP \\
\hline Mean & 3.639497 & -1.961486 & -1.465573 & 25.73901 & 7.207985 & 7.749357 & 0.5684948 \\
\hline Std. dev. & 8.777559 & 1.817068 & 0.5854769 & 1.696719 & 0.426209 & 1.661945 & 0.5101342 \\
\hline Maximum & 19.08063 & 0.9170775 & -0.4559799 & 22.48321 & 6.521856 & 3.951244 & 1.43648 \\
\hline Minimum & -3.74039 & -6.186174 & -2.765193 & 28.59274 & 7.841897 & 10.33799 & -2.014371 \\
\hline Observations & 108 & 108 & 108 & 108 & 108 & 108 & 108 \\
\hline $\mathrm{LnEF}$ & 1 & & & & & & \\
\hline LnREM & $0.2021 * * *$ & 1 & & & & & \\
\hline LnFD & $0.6682 * * *$ & $-0.3483 * * *$ & 1 & & & & \\
\hline LnGDP & $0.2549 * * *$ & $-0.3089 * * *$ & $0.5195 * * *$ & 1 & & & \\
\hline LnENG & $-0.2730 * * *$ & $-0.8294 * * *$ & $0.3945 * * *$ & $0.4103 * * *$ & 1 & & \\
\hline LnTE & $0.6746^{* * *}$ & $-0.3902 * * *$ & $0.8322 * * *$ & $0.4421 * * *$ & $0.4442 * * *$ & 1 & \\
\hline LnURP & 0.0034 & $0.2623 * * *$ & $-0.4694 * * *$ & $-0.8259 * * *$ & $-0.5030 * * *$ & $-0.3811 * * *$ & 1 \\
\hline
\end{tabular}

Note: $* * *$ indicates the level of significance at $1 \%$

GDP illustrates economic growth; ENG indicates energy consumption and URP shows urban population; $i$ and $t$ indicate the four BICS economies and time duration (1990-2016). All variables are converted into a logarithmic form to minimize the problem of data sharpness and heteroscedasticity. Hence, Eq. 1 can be described as follows:

$$
\begin{aligned}
\ln \left(\mathrm{EF}_{\mathrm{it}}\right)= & \beta_{0 \mathrm{it}}+\beta_{1 \mathrm{it}} \ln \left(\mathrm{REM}_{\mathrm{it}}\right)+\beta_{2 \mathrm{it}} \ln \left(\mathrm{TE}_{\mathrm{it}}\right) \\
& +\beta_{3 \mathrm{it}} \ln \left(\mathrm{FD}_{\mathrm{it}}\right)+\beta_{4 \mathrm{it}} \ln \left(\mathrm{GDP}_{\mathrm{it}}\right) \\
& +\beta_{5 \mathrm{it}} \ln \left(\mathrm{ENG}_{\mathrm{it}}\right)+\beta_{6 \mathrm{it}} \ln \left(\mathrm{URP}_{\mathrm{it}}\right)+\mu_{\mathrm{it}}
\end{aligned}
$$

Furthermore, we add GDP square $\left(\mathrm{GDP}^{2}\right)$ to check the validity of the environmental Kuznets curve (EKC) hypothesis. The extended form of the EKC hypothesis can be expressed in Eq. 3 as follows:

$$
\begin{aligned}
\ln \left(\mathrm{EF}_{\mathrm{it}}\right)= & \beta_{0 \mathrm{it}}+\beta_{1 \mathrm{it}} \ln \left(\mathrm{REM}_{\mathrm{it}}\right)+\beta_{2 \mathrm{it}} \ln \left(\mathrm{TE}_{\mathrm{it}}\right) \\
& +\beta_{3 \mathrm{it}} \ln \left(\mathrm{FD}_{\mathrm{it}}\right)+\beta_{4 \mathrm{it}} \ln \left(\mathrm{GDP}_{\mathrm{it}}\right) \\
& +\beta_{5 \mathrm{it}} \ln \left(\mathrm{GDP}_{\mathrm{it}}^{2}\right)+\beta_{6 \mathrm{it}} \ln \left(\mathrm{ENG}_{\mathrm{it}}\right) \\
& +\beta_{7 \mathrm{it}} \ln \left(\mathrm{URP}_{\mathrm{it}}\right)+\mu_{\mathrm{it}}
\end{aligned}
$$

Fig. 3 A and B graph show the BICS countries and global ecological footprint drivers in \% respectively (Global hectares per person in 2016). Source: GFPN (2019)
This current study aims that remittance inflows and financial development, remittance inflows, and technological innovation might have a moderation role besides its direct influence on the ecological footprint in the four BICS economies. Consequently, focusing on this issue, this study attempts to investigate the moderation effect between REM and FD, and REM and TE. We comprise a moderation effect term in Eq. 3 and get a new equation that can be expressed as follows:

$$
\begin{aligned}
\ln \left(\mathrm{EF}_{\mathrm{it}}\right)= & \beta_{0 \mathrm{it}}+\beta_{1 \mathrm{it}} \ln \left(\mathrm{REM}_{\mathrm{it}}\right)+\beta_{2 \mathrm{it}} \ln \left(\mathrm{TE}_{\mathrm{it}}\right) \\
& +\beta_{3 \mathrm{it}} \ln \left(\mathrm{FD}_{\mathrm{it}}\right)+\beta_{4 \mathrm{it}} \ln \left(\mathrm{REM} \mathrm{TE}_{\mathrm{it}}\right. \\
& +\beta_{5 \mathrm{it}} \ln \left(\mathrm{REM}{ }^{*} \mathrm{FD}\right)_{\mathrm{it}}+\beta_{6 \mathrm{it}} \ln \left(\mathrm{GDP}_{\mathrm{it}}\right) \\
& +\beta_{7 \mathrm{it}} \ln \left(\mathrm{GDP}_{\mathrm{it}}^{2}\right)+\beta_{8 \mathrm{it}} \ln \left(\mathrm{ENG}_{\mathrm{it}}\right) \\
& +\beta_{9 \mathrm{it}} \ln \left(\mathrm{URP}_{\mathrm{it}}\right)+\mu_{\mathrm{it}}
\end{aligned}
$$

where $\beta_{0}=\ln \mathbf{A}_{0}$ presents the constant term, $\mu_{i t}$ shows the stochastic error term, and $\boldsymbol{\beta}_{\mathbf{1}} \rightarrow \boldsymbol{\beta}_{\mathbf{9}}$ denotes the elasticity of candidate variables.

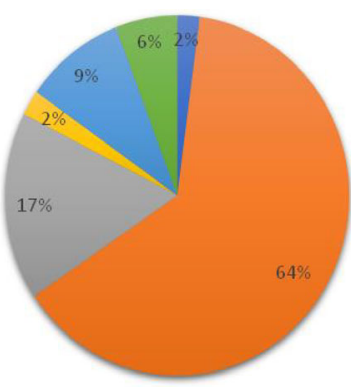

a

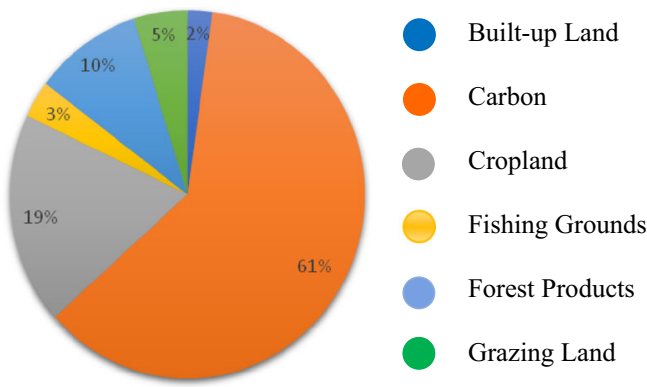

b 


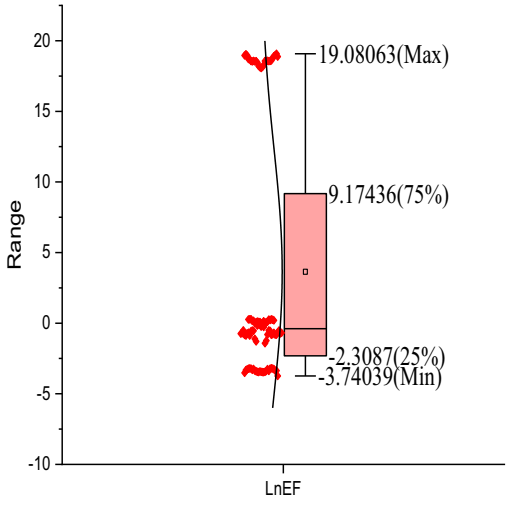

a

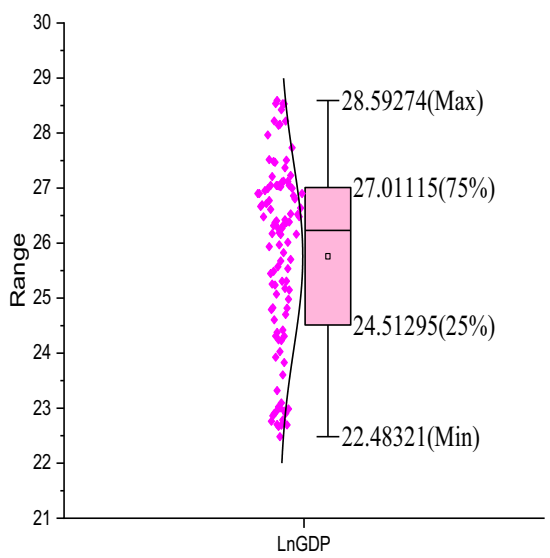

d

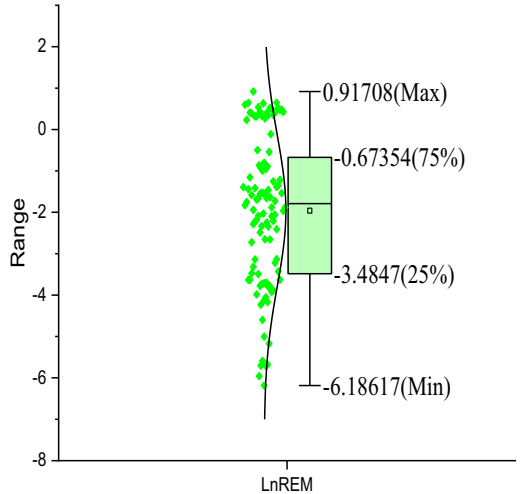

b

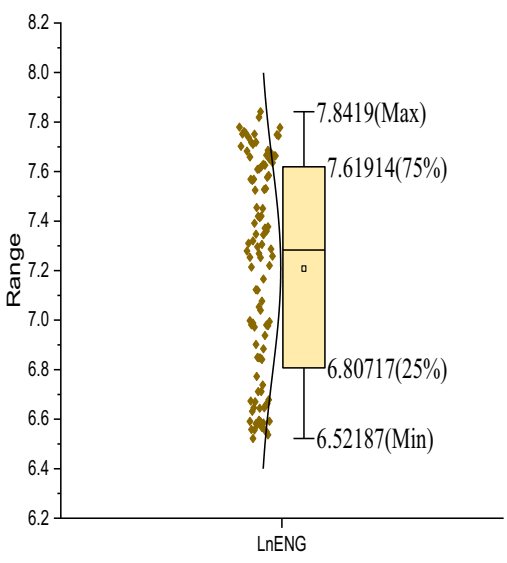

e

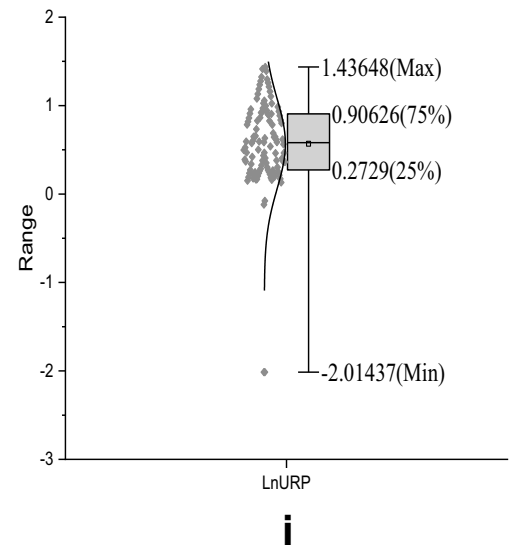

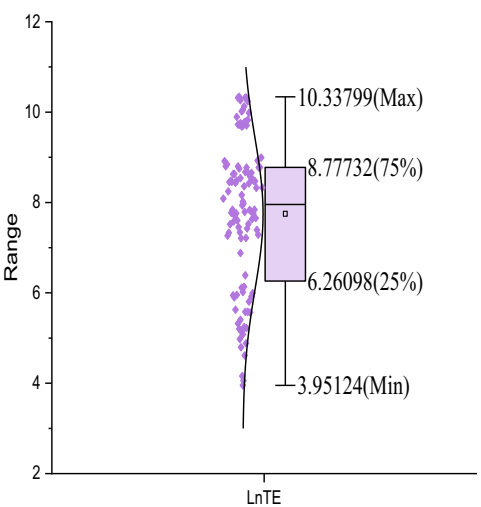

C

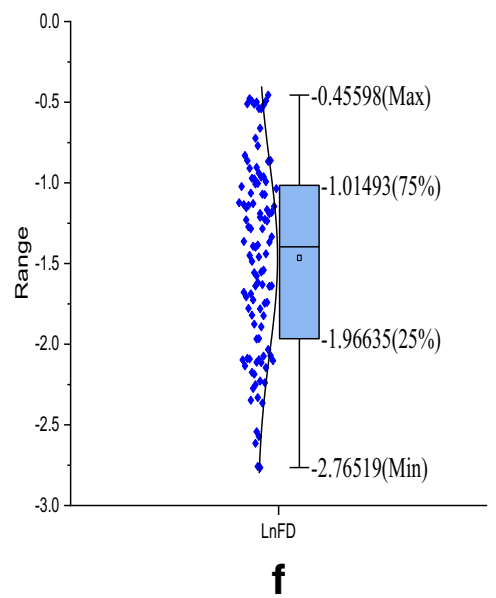

Fig. 4 Box plot summery statistics of our key variables. (a) $\operatorname{lnEP}$. (b) $\operatorname{lnREM}$. (c) $\ln T E$. (d) $\ln G D P$. (e) $\ln E N G$. (f) $\ln F D$. (i) $\ln U R P$

\section{Methodologies framework}

The current study has applied advanced econometric techniques; initially, this study verified the cross-sectional dependency $(\mathrm{CD})$ by using the Breusch-Pagan LM, Pesaran scaled LM, bias-corrected scaled LM, and Pesaran CD methods. This study also applied the cross-section augmented Dickey-Fuller (CADF), and cross-section Im, Pesaran, and Shin (CIPS) panel unit root approaches are used to check the stationary level of the concern variables.
After checking the stationary property of analyzed variables, this study adopted the Westerlund error correction method (ECM) technique for long-run cointegration analysis. This study also applied the dynamic seemingly unrelated regression (DSUR) approach to estimate the long-run elasticity among the aforementioned variables. This study also employed the fully modified ordinary least square (FMOLS) method for country-wise long-run analysis. Finally, this study discovered the granger causality links between candidate variables. 


\section{Cross-sectional dependence tests}

In most of the cases, the panel dataset ignores the problem of $\mathrm{CD}$ that may create biased forecasting, and unreliable outcomes (forecasting error). Following Yang et al. (2020), we applied four different CD techniques, such as (a) Breusch and Pagan (1980) suggested LM test, (b) Pesaran et al. (2008) established LM test, (c) Baltagi et al. (2012) proposed biascorrected scaled LM test, and (d) finally CD test anticipated by Pesaran (2004). The null hypothesis $\left(\mathrm{H}_{0}\right)$ supposes that all variables are $\mathrm{CD}$.

\section{Panel unit root tests}

After checking the CD of data, the next step of the empirical examination is to check the stationary level and instigation level of all our concern variables. The current study applied a second-generation unit roots test to address the CD issue; Pesaran (2007) established a second-generation panel unit test names CIPS and CADF test that addresses the cross-sectional dependence problem across cross-sections. The CAFD test statistics can be expressed in Eq. 5 as follows:

$$
\begin{aligned}
\Delta \mathrm{Y}_{\mathrm{it}}= & \alpha_{\mathrm{i}}+\mathrm{b}_{\mathrm{i}} \mathrm{y}_{\mathrm{i}, \mathrm{t}-1}+\beta_{\mathrm{i}} \overline{\mathrm{y}}_{\mathrm{t}-1}+\sum_{\mathrm{j}=0}^{\mathrm{k}} \mathrm{d}_{\mathrm{ij}} \Delta \overline{\mathrm{y}}_{\mathrm{t}-\mathrm{j}} \\
& +\sum_{\mathrm{j}=1}^{\mathrm{k}} \delta_{\mathrm{ij}} \Delta \mathrm{y}_{\mathrm{i}, \mathrm{t}-\mathrm{j}}+\varepsilon_{\mathrm{it}}
\end{aligned}
$$

where $\overline{\mathbf{y}}_{\mathbf{t}-\mathbf{1}}$ specified the lagged level of cross-sectional averages and $T$ denote the time periods. $\Delta \overline{\mathbf{y}}_{\mathbf{t}-\mathbf{j}}$ represented as the first order of integration for every cross-section. The Pesaran (2007) CIPS unit root test can be specified by obtaining t-statistics value from CADF estimators that are expressed in Eq. 6 as follow:

$$
\mathrm{CIPS}=\mathrm{N}^{-1} \sum_{i=1}^{N} \mathrm{CADF}
$$

\section{Panel cointegration test}

After testing the stationary test, the next step of the econometric procedure is to examine the long-run relationship among candidate variables. Westerlund (2007) anticipated a heterogenous panel cointegration with ECM. Furthermore, Westerlund tests involve four different kinds of test statistics. Two test statistics are based on group statistics $\left(G_{T}\right.$ and $\left.G_{a}\right)$, and the other two are comprised of panel statistics $\left(\mathrm{P}_{\mathrm{T}}\right.$ and $\left.\mathrm{P}_{\mathrm{a}}\right)$. Therefore, following Yang et al. (2020c), this study used Westerlund (2007) cointegration test, because it addresses CD and delivers unbiased results. The ECM based cointegration test is projected by following the least square model as described in Eq. 7 as follows:

$$
\begin{aligned}
\Delta \mathrm{Y}_{\mathrm{it}}= & \delta_{{ }_{\mathrm{i}}}^{\prime} \mathrm{d}_{\mathrm{t}}+\alpha_{\mathrm{i}}\left(\mathrm{Y}_{\mathrm{it}-1}-\beta_{\mathrm{i}}^{\prime} \mathrm{x}_{\mathrm{it}-1}\right)+\sum_{\mathrm{j}=1}^{\mathrm{p}_{\mathrm{i}}} \alpha_{\mathrm{ij}} \Delta \mathrm{y}_{\mathrm{it}-\mathrm{j}} \\
& +\sum_{\mathrm{j}=-\mathrm{p}_{\mathrm{i}}}^{\mathrm{p}_{\mathrm{i}}} \gamma_{\mathrm{ij}} \Delta \mathrm{x}_{\mathrm{i}, \mathrm{t}-\mathrm{j}}+\varepsilon_{\mathrm{it}}
\end{aligned}
$$

Test statistics from group statistics $\left(\mathrm{G}_{\mathrm{T}}\right.$ and $\left.\mathrm{G}_{\mathrm{a}}\right)$ are described by the given Eqs. 8 and 9 as follows:

$\mathrm{G}_{\tau}=\frac{1}{\mathrm{~N}} \sum_{i=1}^{N} \frac{\Psi_{\mathrm{i}}}{\operatorname{SE}\left(\widehat{\Psi}_{\mathrm{i}}\right)}$

$G_{a}=\frac{1}{\mathrm{~N}} \sum_{i=1}^{N} \frac{\mathrm{TY}}{\Psi_{i}^{\prime}(1)}$

Test statistics from panel statistics $\left(\mathrm{P}_{\mathrm{T}}\right.$ and $\left.\mathrm{P}_{\mathrm{a}}\right)$ are expressed in Eqs. 10 and 11 as follows:

$\mathrm{P}_{\tau}=\frac{\widehat{\Psi}_{\mathrm{i}}}{\operatorname{SE}\left(\widehat{\Psi}_{\mathrm{i}}\right)}$

$\mathrm{P}_{\mathrm{a}}=\mathrm{T} \widehat{\Psi}$

where $\boldsymbol{\Psi}_{\mathbf{i}}$ specifies the adjustment speed/short to long-run equilibrium.

\section{Long-run estimation}

Dynamic Seemingly Unrelated Regression For the long-run analysis, the current study used the DSUR method, which is appropriate when the time duration is bigger than the crosssections. We have used the data of four BICS economies from the period of 1990-2016. Therefore, cross-sections are smaller than the time dimension. Second-generation DSUR analysis has the ability to control the cross-sectional dependence and other issues related to panel dataset and generate more reliable outcomes. Following Yang et al. (2020c) and Wang et al. 2020 the current paper employed the DSUR technique to estimate the long-run relationship among the variables.

Fully modified ordinary least square After estimating the long-run cointegration among variables, this study used the FMOLS approach proposed by Pedroni (2001), to check the long-run cointegration for each for every country. The FMOLS technique is more appropriate to overcome the problem of bias, endogeneity, and serial correlation from the predictable coefficient of the panel dataset. Following Usman et al. (2020a, 2020b, 2020c) this study has used for 
FMOLS test for country-wise analysis. For the panel dataset, Pedroni (2001) proposed the following cointegrated estimation.

$X_{i t}=\alpha_{i}+\beta Y_{i t}+\varepsilon_{i t}$

where $Y$ and $X$ are the vector of cointegration. The mathematical explanations are described as follows:

$\widehat{\alpha}_{G F M}^{*}=\mathrm{N}^{-1} \sum_{n=1}^{N} \widehat{\alpha}_{F M, n}^{*}$

where $\widehat{\alpha}_{G F M, n}^{*}$ represents the FMOLS regression which can be applied an individual to all cross-sectionals $n$ and the $t$ statistic coefficient that can be expressed in Eq. 14 as follows:

$$
\underset{\widehat{\alpha}_{G F M}}{\mathrm{t}^{*}}=\mathrm{N}^{-1 / 2} \sum_{n=1}^{N} \underset{\widehat{\alpha}_{F M, n}}{N}
$$

\section{Panel causality estimator}

The final step of the econometric technique is to discover the causality relationship among analyzed variables. Thus, this paper applied Dumitrescu and Hurlin's (D-H) (2012) technique at which solves the problem of cross-sectional dependence and heterogeneity issue, which was unnoticed by the traditional Granger causality estimator (Yang et al. 2020c; Usman et al. 2020c). The D-H approach is based upon Wbar and Z-bar statistics. The null hypothesis $\left(\mathrm{H}_{0}\right)$ tests the nonhomogenous causality of one variable to another.

\section{Results and discussion}

\section{Results of cross-sectional dependence tests}

The first step of econometric analysis is to check the CD issue among the variables by using four different $\mathrm{CD}$ approaches, namely Pesaran CD, Pesaran scaled LM, Breusch-Pagan LM, and bias-corrected scaled LM tests. Table 3 presents the null hypothesis $\left(\mathrm{H}_{0}\right)$ of no cross-sectional independence between cross-sections/countries is rejected at a $1 \%$ level of significance according to all four $\mathrm{CD}$ tests statistics. It displays that disturbance in one country will affect the other country.

\section{Results of panel stationary tests}

After examining the cross-sectional independence test, there is necessary to check the stationary/unit root level and integration order of the variables. To do this, this study used secondgeneration panel unit root tests (i.e., CADF and CIPS). According to Table 4, the results of CIPS unit root test indicate that LnREM and LnENG variables are following the stationary property at level, demonstrating that they reject the null hypothesis of no stationary in the variables. However, all other variables like LnFE, LnFD, LnGDP, LnTE, and LnURP turn to follow the stationarity at their first difference I (1). Regarding the outcomes of CADF reveals that LnFE, LnFD, LnGDP, LnTE, LnURP, and LnENG are non-stationary at levels but all variables are stationary/integrated at the first difference I (1) in the panel of four BICS economies. This outcome reveals that all variables are stationary, and it is suitable to check long-run cointegration among variables.

\section{Results of panel cointegration test}

In order to confirm the long-run association among variables while managing the other econometric problems concerning the panel dataset, the current article employed the secondgeneration panel cointegration test "Westerlund cointegration test." Table 5 presents the outcome of the Westerlund cointegration test is quite mixed in all panels and groups, while ecological footprint was occupied as a dependent variable. The outcomes $\left(\mathrm{G}_{\mathrm{a}}\right.$ and $\left.\mathrm{P}_{\mathrm{a}}\right)$ fail to refuse the null hypothesis (no cointegration), while $\mathrm{G} \tau$ and $\mathrm{P} \tau$ indicate to provide valid evidence of the rejection of the null hypothesis. This confirms that all variables such as LnREM, LnFD, LnGDP, LnENG, LnTE, LnURP, and LnEP comprise a long-run cointegration from 1990 to 2016.

\section{Results of long-run elasticity estimates}

To further discovered the long-run association among LnREM, LnFD, LnGDP, LnENG, LnTE, LnURP, LnREM*LnFD, and LnREM*LnTE and LnEP variables in the cointegration association of panel dataset, this study used the Dynamic Seemingly Unrelated Regression (DSUR) approach. The results as reported in Table 6 demonstrate that all the variables have a significant influence on environmental sustainability (ecological footprint) at $1 \%$ and $5 \%$ level of significance. In Model.1, the coefficient of remittance inflows has an adverse impact on environmental quality, as a $1 \%$ increase in LnREM will lead to an increase of the environmental degradation by $0.9068 \%$ in the long run at $1 \%$ level of significance. As above mentioned in the theoretical framework, remittance inflows enhance the aggregate demand for industrial production with raise the energy utilization (fossil fuel) that deteriorates the environmental quality. This result confirms the previous studies conducted by Yang et al. (2020a) for 97 countries and Brown et al. (2020) for Jamaica's economy. They verify the existence of a positive association between remittance and environmental sustainability. A $1 \%$ increase in financial development causes a $1.4003 \%$ increase in ecological footprint in four BICS countries. In this sense, Jiang and Ma (2019) argued that financial development degrades the environmental quality by 
Table 3 Results of cross-section dependence test

\begin{tabular}{|c|c|c|c|c|c|c|c|c|}
\hline \multirow[t]{2}{*}{ Series } & \multicolumn{2}{|c|}{ Breusch-Pagan } & \multicolumn{2}{|c|}{ Pesaran scaled } & \multicolumn{2}{|c|}{ Bias-corrected scaled } & \multicolumn{2}{|l|}{ Pesaran CD } \\
\hline & Statistic & Prob. & Statistic & Prob. & Statistic & Prob. & Statistic & Prob. \\
\hline LnEF & $35.8673 * * *$ & 0.0000 & $7.46725 * * *$ & 0.0000 & $7.39033^{* * *} *$ & 0.0000 & $4.8327 * * *$ & 0.0000 \\
\hline LnREM & $35.8536^{* * *}$ & 0.0000 & $7.46330 * * *$ & 0.0000 & $7.38638^{* * * *}$ & 0.0000 & $4.1284 * * *$ & 0.0000 \\
\hline LnFD & $15.5627 * * *$ & 0.0000 & $10.6058 * * *$ & 0.0000 & $10.5289 * * *$ & 0.0000 & $2.6784 * * *$ & 0.0000 \\
\hline LnGDP & $82.0423 * * *$ & 0.0000 & $20.7968 * * *$ & 0.0000 & $20.7199 * * *$ & 0.0000 & $8.6229 * * *$ & 0.0000 \\
\hline LnENG & $52.0203 * * *$ & 0.0000 & $12.1302 * * *$ & 0.0000 & $12.0533 * * *$ & 0.0000 & $5.9816 * * *$ & 0.0000 \\
\hline LnURP & 89.3857 *** & 0.0000 & $22.9166 * * *$ & 0.0000 & $22.8397 * * *$ & 0.0000 & $9.2119 * * *$ & 0.0000 \\
\hline LnTE & $53.8296^{* * *}$ & 0.0000 & $12.6525 * * *$ & 0.0000 & $12.5756^{* * *}$ & 0.0000 & $5.6360 * * *$ & 0.0000 \\
\hline
\end{tabular}

Note: $* * *$ indicates the level of significance at $1 \%$.

providing funds/loans to the individual that enhances the buying of energy-intensive appliances i.e., automobiles and other equipment. These results are consistent with the finding of AlMulali et al. (2015), Shahbaz et al. (2016), Bekhet et al. (2017), Yang et al. (2020a, 2020b), and $\mathrm{Lu}$ (2018) and confirmed that financial development enhances the environmental degradation. This outcome of the paper suggests that financial development could improve the environmental quality in BICS economies by channelizing investment/funds for those enterprisers that take green technologies.

The elasticity of technological innovation (TE) is also significant and negative, indicating that a $1 \%$ influence in technological innovation is connected with a 7.9806 decrease in EF. The TE in BICS economies effectively reduces the ecological footprint, which could be seen as eco-friendly technological innovation. The reason may be that if BICS economies attain rapid industrial growth by the features of high-level TE then easily get access/competitive advantage in the international market. Thus, reducing environmental degradation reasoned by production in similar countries. To support these results, Chen and Lee (2020) argued that economic growth improves environmental quality, and this possible only

Table 4 Outcomes of panel unit root test

\begin{tabular}{|c|c|c|c|c|}
\hline \multirow[t]{2}{*}{ Variables } & \multicolumn{2}{|l|}{ CIPS } & \multicolumn{2}{|l|}{ CADF } \\
\hline & At level & 1st difference & At level & 1st difference \\
\hline $\mathrm{LnEF}$ & -1.205 & $-3.345 * * *$ & -1.883 & $-2.907 * * *$ \\
\hline LnREM & $-2.814 * * *$ & $-4.272 * * *$ & $-3.588 * * *$ & $-4.205 * * *$ \\
\hline LnFD & -2.118 & $-5.116^{* * *}$ & -2.346 & $-3.900 * * *$ \\
\hline LnGDP & -0.356 & $-3.899 * * *$ & -0.809 & $-2.239 * * *$ \\
\hline LnENG & $-2.465 * *$ & $-5.486^{* * *}$ & -1.898 & $-4.439 * * *$ \\
\hline LnTE & -0.625 & $-4.476 * * *$ & -1.020 & $-3.942 * * *$ \\
\hline LnURP & -1.118 & $-4.601 * * *$ & -1.261 & $-2.761 * *$ \\
\hline
\end{tabular}

Note: $* * * * *$, and $*$ indicate significance level at $1 \%, 5 \%$, and $10 \%$

through technological innovation/eco-friendly technologies. These findings are similar to those found by Chen and Lee (2020), Yu and Du (2019), Brandão Santana et al. (2015), Zhou et al. (2016), Gerlagh (2007), and Sagar and Holdren (2002). Likewise, in model 1, the positive and negative values of the coefficient of GDP and $\mathrm{GDP}^{2}$ on ecological footprint have expressed the concept of the environmental Kuznets curve (EKC) hypothesis. In short, this empirical find evidence of the inverted U-shaped EKC hypothesis. It is noted a $1 \%$ increase in GDP will lead to an increase in the ecological footprint by $13.1103 \%$, while, a $1 \%$ increase in $\mathrm{GDP}^{2}$ will lead to a decrease in EF by $0.3654 \%$. This conclusion is consistent with the prior work of Destek and Sarkodie (2019) and Katircioglu et al. (2018). Regarding the coefficient of LnENG, it has positive and significant influence on the environmental sustainability. More specifically, $1 \%$ increases in LnENG leads to $0.0060 \%$ increase the EF in BICS economies. This conclusion is consistent with the finding of Yang et al. (2020a). Regarding the elasticity of LnURP, it is also statistically significant and positive stimulus effect on LnEF the outcomes discover that a $1 \%$ influence in LnURP will leads to enhance the environmental degradation by $5.0617 \%$. This finding is similar to those found by Bai et al. (2019).

Table 5 and model 2 show the moderation effect between remittance inflows and financial development on ecological footprint. The result of the interaction term (LnREM*LnFD) shows a significant and negative influence on LnEP. It

Table 5 Outcomes of Westerlund panel cointegration test

\begin{tabular}{llll}
\hline Test & Stat. value & $Z$-value & $P$ value \\
\hline $\mathrm{G}_{\mathrm{t}}$ & $-3.700^{* * *}$ & -5.363 & 0.000 \\
$\mathrm{G}_{\mathrm{a}}$ & -5.284 & 2.650 & 0.914 \\
$\mathrm{P}_{\mathrm{t}}$ & $-3.135^{* * *}$ & -8.875 & 0.000 \\
$\mathrm{P}_{\mathrm{a}}$ & -6.433 & 2.530 & 0.937 \\
\hline
\end{tabular}

***Rejection of null hypothesis at a level of $1 \%$ 
Table 6 Results of long-run estimations through DSUR

\begin{tabular}{|c|c|c|c|c|c|c|c|c|c|}
\hline \multirow[t]{2}{*}{ Variables } & \multicolumn{3}{|l|}{ Model 1} & \multicolumn{3}{|l|}{ Model 2} & \multicolumn{3}{|l|}{ Model 3} \\
\hline & Coefficient & $t$-value & $P$ value & Coefficient & $\begin{array}{l}t- \\
\text { value }\end{array}$ & $P$ value & Coefficient & $\begin{array}{l}t- \\
\text { value }\end{array}$ & $P$ value \\
\hline LnREM & $0.9068 * * *$ & 5.39 & 0.000 & $3.7306^{* * * *}$ & 8.56 & 0.000 & $3.8458 * * *$ & 3.48 & 0.000 \\
\hline LnFD & $1.4003 * * *$ & 6.15 & 0.000 & $3.1813 * *$ & 2.28 & 0.023 & $1.5847 * * *$ & 5.57 & 0.000 \\
\hline LnGDP & $13.1103 * * *$ & 8.44 & 0.000 & $12.599 * * *$ & 9.69 & 0.000 & $10.869 * * *$ & 7.13 & 0.000 \\
\hline LnGDP $^{2}$ & $-0.3654 * * *$ & -7.45 & 0.000 & $-0.3540 * * *$ & -8.63 & 0.000 & $-0.3029 * * *$ & -6.38 & 0.000 \\
\hline LnENG & $0.0060 * * *$ & 9.91 & 0.000 & $0.0073 * * *$ & 9.50 & 0.000 & $0.0069 * * *$ & 9.91 & 0.000 \\
\hline LnURP & $5.0617 * * *$ & 15.75 & 0.000 & $3.9233^{* * * *}$ & 12.42 & 0.000 & $4.7573 * * *$ & 15.62 & 0.000 \\
\hline LnTE & $-7.9806^{* * *}$ & -13.11 & 0.000 & $6.3459 * * *$ & 11.30 & 0.000 & $9.2328 * * *$ & 14.63 & 0.000 \\
\hline LnREM*LnFD & & & & $-0.7842 * * *$ & -2.82 & 0.000 & & & \\
\hline LnREM*LnTE & & & & & & & $-0.5962 * * *$ & -3.43 & 0.000 \\
\hline
\end{tabular}

Note: $* * *, * *$, and $*$ indicate significance level at $1 \%, 5 \%$, and $10 \%$ respectively.

discloses that an increase in remittance inflows with the integration of financial development increase then financial sectors are given more investment/incentive for eco-friendly technologies that are likely to reduce environmental degradation. When the financial sector in the BICS economies starts growing with proper channels, then the remittance will be received with an appropriate mechanism. As a result, the financial sector would allocate more subsidies/funds for ecofriendly technologies in the future. So, BICS economies should enhance their financial institutes to overcome the problem of remittance inflows to protect environmental quality. According to model 3, results show the coefficient of interaction term (LnREM*LnTE) significantly negative influence on LnEP, which shows that LnTE adversely moderates the impact of remittance inflows on ecological footprint. Technical innovation facilitates the remittances that are seen as a contribution to a potential opportunity like mobile banking services and mobile phone networks to overseas/migrant people which will use formal channels to send their remittance cheaper and faster in the domestic country. However, these formal channels are likely to improve economic growth with less environmental degradation.

\section{Results of country-wise long-run elasticity estimates}

The long-run elasticity estimation of the BICS panel is before reflected in the previous part of this paper. However, the dynamic relationship among remittance inflows, financial development, technological innovation, and ecological footprint for country-wise analyses is mandatory for healthier policy formulation. Furthermore, this study estimates the coefficient of these analyzed variables for each BICS economies. The FMOLS approach is applied for the country-wise estimation of long-run elasticity analysis. The results are reported in Table 7. These results show that remittance inflows
(REM) have a positive and significant impact on environmental degradation in BICS economies. Particularly, a $1 \%$ increase in LnREM leads to an increase in the LnEF in the case of Brazil, India, China, and South Africa by $0.0115 \%, 0.0705 \%, 0.0193 \%$, and $0.0443 \%$ respectively in model 1. In general, REM boosts the aggregate demand for industrial production, more energy demand in these economies upsurges the utilization of fossil fuels, which reasoned for the degradation of the environmental quality, as we discuss in the previous part (overall panel). These results are consistent with the finding of Yang et al. (2020a).

Regarding the coefficient of financial development, it has a significantly positive impact on LnEF in BICS economies. More specifically, a $1 \%$ increase in LnFD will lead to $0.1836 \%, 0.0063 \%, 0.4204 \%$, and $0.0251 \%$ increase in environmental degradation in Brazil, India, China, and South Africa respectively. Therefore, these outcomes advice to the government of BICS economies should support to establish a well-designed financial system/sector that given more subsidies/founds for those investors that are trying to install the eco-friendly technologies for their production activities, aiming at growing/evolving in a cleaner and renewable energy. Moreover, technological innovation (TE) has a negative impact on the ecological footprint in BICS economies. A $1 \%$ increase in LnTE leads to a decrease in the LnEF in the case of Brazil, India, China, and South Africa by $0.0322 \%$, $0.1118 \%, 0.1849 \%$, and $0.0151 \%$ respectively. These results explore that BICS economies should have strong capabilities and motivation to grow eco-friendly technological innovations. It is observed that TE plays a positive role in ecological footprint reduction, implying that TE in BICS economies is not only conducive to the development of domestic environmental sustainability but also helps to minimize environmental degradation. 
Table 7 Results of country-wise long-run estimations (FMOLS)

\begin{tabular}{|c|c|c|c|c|c|c|c|c|c|}
\hline \multirow[t]{2}{*}{ Variables } & \multicolumn{3}{|l|}{ Model 1} & \multicolumn{3}{|l|}{ Model 2} & \multicolumn{3}{|l|}{ Model 3} \\
\hline & Coefficient & $t$-value & $P$ value & Coefficient & $t$-value & $P$ value & Coefficient & $t$-value & $P$ value \\
\hline \multicolumn{10}{|l|}{ Brazil } \\
\hline LnREM & 0.0115 & 0.73 & 0.474 & $0.8754 *$ & 1.90 & 0.074 & $1.3554 * * *$ & 3.28 & 0.004 \\
\hline LnFD & $0.1836^{* * *}$ & 3.27 & 0.004 & $0.2779 * *$ & 2.46 & 0.025 & $0.1833 * * *$ & 3.68 & 0.002 \\
\hline LnGDP & $11.5291 * * *$ & 3.02 & 0.007 & 2.1976 & 0.42 & 0.676 & $-0.7612 * * *$ & -3.73 & 0.002 \\
\hline LnGDP $^{2}$ & $-0.4861 * * *$ & -2.91 & 0.009 & -0.0660 & -0.29 & 0.777 & $0.0668 * * *$ & 10.16 & 0.000 \\
\hline LnENG & $0.5483 * *$ & 2.42 & 0.026 & 0.1562 & 0.51 & 0.620 & 0.0751 & 0.32 & 0.752 \\
\hline LnURP & 0.0644 & 0.59 & 0.561 & 0.0585 & 0.47 & 0.646 & 0.0621 & 0.61 & 0.547 \\
\hline LnTE & -0.0322 & -0.43 & 0.676 & 0.1154 & 1.28 & 0.218 & 0.0979 & 1.41 & 0.175 \\
\hline LnREM*LnFD & & & & -0.0287 & 1.05 & 0.037 & & & \\
\hline LnREM*LnTE & & & & & & & $-0.0182 * *$ & -2.29 & 0.034 \\
\hline \multicolumn{10}{|l|}{ India } \\
\hline LnREM & $0.0705^{* *}$ & 2.73 & 0.013 & $0.5686^{* * *}$ & 3.03 & 0.007 & $0.7051 * *$ & 2.83 & 0.011 \\
\hline LnFD & 0.0063 & 0.10 & 0.918 & $1.0987 * * *$ & 4.36 & 0.000 & 0.0282 & 0.54 & 0.598 \\
\hline LnGDP & -2.7239 & -1.18 & 0.255 & -1.1881 & -0.81 & 0.428 & $0.8089 * * *$ & 3.75 & 0.002 \\
\hline LnGDP $^{2}$ & 0.1213 & 1.24 & 0.229 & 0.0565 & 0.92 & 0.371 & $-0.0272 * * *$ & -2.97 & 0.008 \\
\hline LnENG & $0.6185^{* * *}$ & 3.46 & 0.003 & $0.4490 * * *$ & 3.98 & 0.001 & 0.2669 & 1.59 & 0.127 \\
\hline LnURP & $0.2216^{* * *}$ & 3.62 & 0.002 & -0.0124 & -0.51 & 0.618 & 0.0430 & 1.39 & 0.179 \\
\hline LnTE & $-0.1118 * * *$ & -3.87 & 0.001 & $0.0971 * * *$ & 5.15 & 0.000 & 0.0366 & 1.07 & 0.298 \\
\hline LnREM*LnFD & & & & $-0.1798 * * *$ & -3.68 & 0.001 & & & \\
\hline LnREM*LnTE & & & & & & & $-0.0692 * *$ & -2.64 & 0.017 \\
\hline \multicolumn{10}{|l|}{ China } \\
\hline LnREM & 0.0193 & 0.15 & 0.882 & -1.4192 & -1.23 & 0.233 & 0.9137 & 1.70 & 0.106 \\
\hline LnFD & $0.4204^{* *}$ & 2.65 & 0.016 & $0.4771 * *$ & 2.29 & 0.034 & 0.2391 & 1.62 & 0.123 \\
\hline LnGDP & -17.1122 & -1.42 & 0.173 & $-2.3469 * * *$ & -4.49 & 0.000 & $-2.333 * * *$ & -4.41 & 0.000 \\
\hline LnGDP $^{2}$ & 0.7722 & 1.32 & 0.202 & $0.0623 * *$ & 2.29 & 0.035 & $0.0664 * *$ & 2.42 & 0.027 \\
\hline LnENG & $2.6687 * * *$ & 6.32 & 0.000 & $2.5927 * * *$ & 5.87 & 0.000 & $2.3758 * * *$ & 5.05 & 0.000 \\
\hline LnURP & $-1.0021 * * *$ & -3.51 & 0.003 & $-0.7383 * * *$ & -2.89 & 0.009 & $-0.6749 * * *$ & -2.63 & 0.017 \\
\hline LnTE & -0.1849 & -1.67 & 0.111 & $0.2398 * *$ & 2.16 & 0.044 & $0.2933^{* *}$ & 2.53 & 0.021 \\
\hline LnREM*LnFD & & & & -0.5719 & -1.19 & 0.250 & & & \\
\hline LnREM*LnTE & & & & & & & $-0.1965^{*}$ & -1.88 & 0.077 \\
\hline \multicolumn{10}{|l|}{ South Africa } \\
\hline LnREM & $0.0443 * * *$ & 3.29 & 0.004 & $0.3762 *$ & 2.10 & 0.051 & $1.3961 * * *$ & 4.26 & 0.000 \\
\hline LnFD & 0.0251 & 0.20 & 0.843 & $1.0122 * *$ & 2.21 & 0.041 & 0.0170 & 0.19 & 0.846 \\
\hline LnGDP & 8.2896 & 1.32 & 0.203 & $12.9111 * *$ & 2.50 & 0.023 & $11.9635 * *$ & 2.77 & 0.013 \\
\hline LnGDP $^{2}$ & -0.3605 & -1.28 & 0.214 & $-0.5605^{* *}$ & -2.45 & 0.124 & $-0.5212 * *$ & -2.71 & 0.015 \\
\hline LnENG & 0.3957 & 1.59 & 0.129 & -0.3215 & -1.62 & 0.000 & -0.1740 & -1.02 & 0.322 \\
\hline LnURP & $0.1372 * * *$ & 4.19 & 0.001 & $0.1214 * * *$ & 4.57 & 0.606 & $0.1106^{* * *}$ & 4.77 & 0.000 \\
\hline LnTE & -0.0151 & -0.27 & 0.794 & 0.0239 & 0.53 & 0.032 & $0.7843 * * *$ & 4.48 & 0.000 \\
\hline LnREM*LnFD & & & & $-0.2267 * *$ & -2.33 & 0.017 & & & \\
\hline LnREM*LnTE & & & & & & & $-0.1878^{* * *}$ & -4.38 & 0.000 \\
\hline
\end{tabular}

Note: $* * * * *$, and $*$ indicate significance level at $1 \%, 5 \%$, and $10 \%$

Conversely, the coefficient value of GDP and square of GDP is 11.5292 and -0.4861 , respectively, which suggests that GDP enhances, ecological footprint also enhances with the passage of time. However, it declines after passing the turning point of GDP growth, which confirms the presence of the EKC hypothesis in the case of Brazil. Similarly, the positive and negative values of the coefficient of GDP and $\mathrm{GDP}^{2}$ are 8.2896 , and -0.3605 which has also supported 
the presence of the inverted U-shaped EKC hypothesis in the case of the South Africa economy. These results are consistent with the finding of Apergis et al. (2017) and Apergis and Payne (2009). Furthermore, the elasticity of GDP and GDP2 is -2.7239 and 0.1213 are reported in Table 7. These empirical results also support the validity of the U-shaped EKC hypothesis in the case of China as it is the same for India state. This finding is consistent with those found by Dogan et al. (2017) and Dogan and Turkekul (2016). It also recommends that the government of Russia and India should make an effective strategy to develop energy-saving and eco-friendly projects (renewable energy). Furthermore, the outcomes of the energy utilization coefficient indicating that it has a statically significant and positive influence on the ecological footprint in BICS economies. Moreover, a $1 \%$ increase in LnENG will lead to an increase in the LnEF in the case of Brazil, India, China, and South Africa by $0.5483 \%, 0.6185 \%, 2.6687 \%$, and $0.3957 \%$ respectively. In this case, we recommend to the governments and policymakers will provide more subsidies/funds for eco-friendly technologies and install clean power generation projects. Such findings are consistent with those of Yang et al. (2020a) and Wu et al. (2020).

Furthermore, the long-run elasticity of ecological footprint related to interaction terms between remittance inflows s and financial development has a found a negative impact on environmental degradation in the case of BICS countries in Model2. More precisely, a $1 \%$ increase in interaction term (LnREM*LnFD) will lead to an increase LnEF in the case of Brazil, India, China, and South Africa by $0.0287 \%$, $0.1798 \%, 0.5719 \%$, and $0.2267 \%$ respectively. The public and private partnership among remittance companies/ financial sectors of these countries need to be established to minimize the informal channels of remittances, presenting lower transaction costs, along with concessions for regular remittance senders, may inspire migrant employees to send money formally and frequently. Additionally, the outcomes of the interaction term between remittance inflows and technological innovation indicating that it has a significant and negative influence on the ecological footprint in the BICS countries in Model 3.A 1\% increase in LnREM*LnTE leads to an increase the ecological footprint in the case of Brazil, India, China, and South Africa by $0.0182 \%, 0.0692 \%$, $0.1965 \%$, and $0.1878 \%$ respectively. Technological improvements have allowed for faster, lower-cost mechanisms for the international transfer of payment among individuals. The outcomes of the control variables are varied and reliable with the empirical and theoretical literature and identified no anomaly concerning the conclusions of control variables.

\section{Results of Dumitrescu-Hurlin panel causality}

Finally, the last step of the econometric procedure of empirical analysis is to discover the causality directions among the analyzed variables, i.e., remittance inflows, financial development, economic growth, energy utilization, technological innovation urban population, and ecological footprint. The direction of causality would help the government/policymakers to make suitable environmental policies in the BICS countries. For this purpose, we used the Dumitrescu-Hurlin panel causality approach to verify the causal links among the concern variables. The way of causality can be identified from the coefficients of the significance level of the candidate variables. Table $8 \mathrm{ex}-$ plores that a unidirectional causality association is discovered from ecological footprint to remittance inflow, from ecological footprint to financial development, from ecological footprint to economic growth, from ecological footprint to economic growth square, from remittance inflow to financial development, from remittance inflows to economic growth, from financial development to economic growth, from financial development to economic growth square, from financial development to energy consumption, from economic growth to technological innovation in the whole panel data of BICS countries. In contrast, a bidirectional causality association is revealed between ecological footprint and technological innovation. Ke et al. (2020) also reveal similar findings. The bidirectional relationship is also observed between financial and technological innovation. Ibrahiem (2020) also confirm a similar causal association for Egypt. Two causal linkages are also observed between financial development and urban population, which is parallel to the conclusion of Sbia et al. (2017). Furthermore, the bidirectional association is also noticed between economic growth and urban population. Zhao and Wang (2015) also confirm a similar causal association from China. Furthermore, there is no causality association observed among financial development to energy consumption, and remittance inflows to energy consumption, and remittance inflow to technological innovation, and remittance inflow to the urban population, and economic growth to economic growth square and energy consumption to technological innovation. These findings are consistent in line with some previous studies, i.e., Khalid et al. (2020), Yang et al. (2020c), and Usman et al. (2020a, 2020c) in the case of different regions/ countries studies. The findings from Table 8 will provide significant help to central authority and policymakers in formulating and implementation of efficient policies (control pollution level) for the BICS countries in the future.

\section{Conclusion and policy implication}

This study explored the impact of remittance inflows, technological innovation and financial development with the interaction term (LnREM*LnFD) (LnREM*LnTE) on the ecological footprint in the case of BICS economies. The ecological footprint based on six different environmental indicators is applied to measure the environmental degradation (Ozcan et al. 2018; Usman et al. 2020a, 2020b, 2020c; Lin et al. 
2020; Hassan et al. 2019) which is ignored by the prior researchers. The panel data from 1990 to 2016 is analyzed through second-generation advance econometric techniques, For Cross-sectional independence four different $\mathrm{CD}$ tests were used to check CD across cross-sections, CIPS and CADF were applied to investigate the stationary level, and Westerlund (2007) cointegration test was employed to check the long-run association among concerned variables. Furthermore, this paper uses the DSUR, and FMOLS estimator was applied to estimate the long-run relationship and finally, Dumitrescu and Hurlin (2012) panel causality technique was used to verify the causality link between candidate variables.

The findings from the DSUR approach show that remittance inflows and financial development are significantly deteriorating the environmental sustainability in BICS economies. This paper found a significant and negative influence of technological innovation on ecological footprint. Furthermore, the results of interaction terms (LnREM*LnFD and LnREM*LnTE) disclose a significant negative influence on environmental degradation. Moreover, the empirical results confirm the validity of the EKC hypothesis. More specifically, the country-wise FMOLS findings indicate that remittance inflows and financial development have a positive and significant influence on environmental degradation. In contrast, technological innovation has an adverse effect on environmental sustainability in the case of BICS countries. Additionally, we have checked the country-wise EKC hypothesis, and interestingly, our results confirm the evidence of the inverted U-shaped EKC hypothesis in the case of Brazil and South Africa, while a U-shaped EKC hypothesis has been found in the case of India and China economies. Moreover, the panel D-H causality outcomes indicate that a bidirectional causality was discovered between LnEF and LnTE, between LnFD and LnTE, between LnFD and LnURP, between LnGDP and LnURP, and finally between $\operatorname{LnGDP}^{2}$ and LnURP in the case of analyzed BICS economies.

Based on the abovementioned findings, this study suggests the following policy implication to the stakeholders, governments, and policymakers, in general/precisely regarding the BICS economies for environmental quality. Firstly, remittance inflows have an adverse effect on environmental sustainability in BICS economies. This suggests that remittance increase the household's income that rise the use of energyintensive products, i.e., automobiles, etc., and thereby deteriorate environmental quality. Therefore, environmental sustainability is questionable in BICS economies. Remittance inflows as measured a vital determination of financial sectors and GDP. However, the government of BICS economies should address the contrary influence of remittance inflows on ecological footprint and environmental sustainability by putting strict restrictions on high polluted manufacturers/ industries through harsh financial rules. To address these 
concerns, environmental sustainability advantages of remittance inflows can also be gained by providing the incentives/subsidies to eco-friendly technologies or handover from the developed world. Thereby, the government of BICS economies can alleviate the adverse influence of remittance inflows on ecological footprint and get environmental sustainability development of remittance inflows.

Secondly, the positive relationship between financial development and ecological footprint shows that financial development significantly degrades environmental quality. The major reason is that the enterprises/investors are concentrating on the expansion of economic growth scale rather than credit finance for installing eco-friendly production technologies. Hence, this study recommends the government and policymakers of BICS economies should impose strict financial rules and monitoring channels about ecologically sustainable finance to distract extensive financial capital and improve the environmental quality through research and development (R\&D) or technology transfer from developed countries. The eco-friendly technologies will not only reservation the capabilities of the BICS economies at the international level but also will ensure environmental sustainability in the long-term. The less polluted growth process may be probable only if the BICS economies shift conventional energy (fossil fuels) to clean (renewable energy) energy sources. The government must invest in the industrial/agriculture sector to promote renewable energy development and technological innovations.

This study has some limitations which can be pointed out in future research works. Since, we do not consider the important variables like institutional quality, globalization in our analytical framework. Future researchers could also extend this study by examining the role of institutional quality, globalization, remittance inflows, and ecological footprint in the framework of pollution haven or halo hypothesis and make a considerable contribution to literature and suggest some practical policy implications.

Acknowledgments The authors express their gratitude to the anonymous reviewers for the efforts in reviewing the paper and suggesting key modifications that have enhanced the quality of the article. The authors also appreciate the editor for his cooperation during the review process.

Authors' contributions Conceptualization, AJ. Methodology and software, AJ and MA. Formal analysis, AJ and MA. Data collection. AJ. Writing-original draft preparation, AJ. Writing-review and editing, BY, MA, and AJ. Supervision, BY. Project administration, AJ. All authors have read and approved the manuscript.

Data availability The datasets used and/or analyzed during the current study are variability from the corresponding author on reasonable request.

\section{Compliance with ethical standards}

Ethics approval and consent to participate Not applicable
Consent for publication Not applicable

Competing interests The authors declare that they have no competing interests

\section{References}

Ahmad M, U1 Haq Z, Khan Z, Khattak SI, Ur Rahman Z, Khan S (2019) Does the inflow of remittances cause environmental degradation? Empirical evidence from China. Econ Res-Ekonomska istraživanja 32(1):2099-2121. https://doi.org/10.1080/1331677X.2019. 1642783

Ahmed Z, Zafar MW, Mansoor S (2020) Analyzing the linkage between military spending, economic growth, and ecological footprint in Pakistan: evidence from cointegration and bootstrap causality. Environ Sci Pollut Res 27(33):41551-41567. https://doi.org/10. 1007/s11356-020-10076-9

Al-Mulali U, Ozturk I, Lean HH (2015) The influence of economic growth, urbanization, trade openness, financial development, and renewable energy on pollution in Europe. Nat Hazards 79(1):621644. https://doi.org/10.1007/s11069-015-1865-9

Al-Mulali U, Solarin SA, Sheau-Ting L, Ozturk I (2016) Does moving towards renewable energy cause water and land inefficiency? An empirical investigation. Energy Policy 93:303-314. https://doi.org/ 10.1016/j.enpol.2016.03.023

Amin A, Dogan E, Khan Z (2020) The impacts of different proxies for financialization on carbon emissions in top-ten emitter countries. Sci Total Environ 740:140127-140127. https://doi.org/10.1016/j. scitotenv.2020.140127

Ang JB (2009) CO2 emissions, research and technology transfer in China. Ecol Econ 68(10):2658-2665. https://doi.org/10.1016/j. ecolecon.2009.05.002

Apergis N, Payne JE (2009) CO2 emissions, energy usage, and output in Central America. Energy Policy 37(8):3282-3286. https://doi.org/ 10.1016/j.enpol.2009.03.048

Apergis N, Christou C, Gupta R (2017) Are there environmental Kuznets curves for US state-level CO2 emissions? Renew Sust Energ Rev 69:551-558. https://doi.org/10.1016/j.rser.2016.11.219

Așıcı AA, Acar S (2018) How does environmental regulation affect production location of non-carbon ecological footprint? J Clean Prod 178:927-936. https://doi.org/10.1016/j.jclepro.2018.01.030

Aziz N, Sharif A, Raza A, Rong K (2020) Revisiting the role of forestry, agriculture, and renewable energy in testing environment Kuznets curve in Pakistan: evidence from Quantile ARDL approach. Environ Sci Pollut Res 27(9):10115-10128. https://doi.org/10.1007/s11356020-07798-1

Bai Y, Deng X, Gibson J, Zhao Z, Xu H (2019) How does urbanization affect residential $\mathrm{CO} 2$ emissions? An analysis on urban agglomerations of China. J Clean Prod 209:876-885. https://doi.org/10.1016/j. jclepro.2018.10.248

Baltagi BH, Feng Q, Kao C (2012) A Lagrange multiplier test for crosssectional dependence in a fixed effects panel data model. J Econ 170(1):164-177. https://doi.org/10.1016/j.jeconom.2012.04.004

Basnet HC, Upadhyaya KP (2014) Do remittances attract foreign direct investment? An empirical investigation. Glob Econ J 14(1):1-9. https://doi.org/10.1515/gej-2013-0052

Bekhet HA, Matar A, Yasmin T (2017) CO2 emissions, energy consumption, economic growth, and financial development in GCC countries: dynamic simultaneous equation models. Renew Sust Energ Rev 70:117-132. https://doi.org/10.1016/j.rser.2016.11.089

Bhattacharya H (2020) Environmental and socio-economic sustainability in India: evidence from $\mathrm{CO} 2$ emission and economic inequality 
relationship. J Environ Econ Policy 9(1):57-76. https://doi.org/10. 1080/21606544.2019.1604267

Brandão Santana N, Rebelatto DADN, Périco AE, Moralles HF, Leal Filho W (2015) Technological innovation for sustainable development: an analysis of different types of impacts for countries in the BRICS and G7 groups. Int J Sustain Dev World Ecol 22(5):425436. https://doi.org/10.1080/13504509.2015.1069766

Breusch TS, Pagan AR (1980) The Lagrange multiplier test and its applications to model specification in econometrics. Rev Econ Stud 47(1):239-253. https://doi.org/10.2307/2297111

Brown L, McFarlane A, Campbell K, Das A (2020) Remittances and $\mathrm{CO} 2$ emissions in Jamaica: an asymmetric modified environmental Kuznets curve. J Econ Asymmetries 22:e00166. https://doi.org/10. 1016/j.jeca.2020.e00166

Canadell JG, Le Quéré C, Raupach MR, Field CB, Buitenhuis ET, Ciais P et al (2007) Contributions to accelerating atmospheric CO2 growth from economic activity, carbon intensity, and efficiency of natural sinks. Proc Natl Acad Sci 104(47):18866-18870. https://doi.org/10. 1073/pnas.0702737104

Cetin M, Ecevit E, Yucel AG (2018) The impact of economic growth, energy consumption, trade openness, and financial development on carbon emissions: empirical evidence from Turkey. Environ Sci Pollut Res 25(36):36589-36603. https://doi.org/10.1007/s11356018-3526-5

Chen Y, Lee CC (2020) Does technological innovation reduce CO2 emissions? Cross-country evidence. J Clean Prod 263:121550. https://doi.org/10.1016/j.jclepro.2020.121550

Cheng C, Ren X, Wang Z (2019) The impact of renewable energy and innovation on carbon emission: an empirical analysis for OECD countries. Energy Procedia 158:3506-3512. https://doi.org/10. 1016/j.egypro.2019.01.919

Chowdhury M (2016) Financial development, remittances and economic growth: evidence using a dynamic panel estimation. Margin J Appl Econ Res 10(1):35-54. https://doi.org/10.1177/0973801015612666

Costantini V, Crespi F, Marin G, Paglialunga E (2017) Eco-innovation, sustainable supply chains and environmental performance in European industries. J Clean Prod 155:141-154. https://doi.org/10. 1016/j.jclepro.2016.09.038

De PK, Ratha D (2012) Impact of remittances on household income, asset and human capital: evidence from Sri Lanka. Migr Dev 1(1):163179. https://doi.org/10.1080/21632324.2012.719348

Destek MA, Sarkodie SA (2019) Investigation of environmental Kuznets curve for ecological footprint: the role of energy and financial development. Sci Total Environ 650:2483-2489. https://doi.org/10. 1016/j.scitotenv.2018.10.017

Dogan E, Turkekul B (2016) CO 2 emissions, real output, energy consumption, trade, urbanization and financial development: testing the EKC hypothesis for the USA. Environ Sci Pollut Res 23(2):12031213. https://doi.org/10.1007/s11356-015-5323-8

Dogan E, Seker F, Bulbul S (2017) Investigating the impacts of energy consumption, real GDP, tourism and trade on $\mathrm{CO} 2$ emissions by accounting for cross-sectional dependence: a panel study of OECD countries. Curr Issue Tour 20(16):1701-1719. https://doi.org/10. 1080/13683500.2015.1119103

Dogan E, Taspinar N, Gokmenoglu KK (2019) Determinants of ecological footprint in MINT countries. Energy \& Environment 30(6): 1065-1086. https://doi.org/10.1177/0958305X19834279

Dogan E, Ulucak R, Kocak E, Isik C (2020) The use of ecological footprint in estimating the environmental Kuznets curve hypothesis for BRICST by considering cross-section dependence and heterogeneity. Sci Total Environ 273:138063. https://doi.org/10.1016/j. scitotenv.2020.138063

Dumitrescu EI, Hurlin C (2012) Testing for Granger non-causality in heterogeneous panels. Econ Model 29(4):1450-1460. https://doi. org/10.1016/j.econmod.2012.02.014
Fei Q, Rasiah R, Shen LJ (2014) The clean energy-growth nexus with $\mathrm{CO} 2$ emissions and technological innovation in Norway and New Zealand. Energy Environ 25(8):1323-1344. https://doi.org/10.1260/ 0958-305X.25.8.1323

Gerlagh R (2007) Measuring the value of induced technological change. Energy Policy 35(11):5287-5297. https://doi.org/10.1016/j.enpol. 2006.01.034

GFPN (2019) Global footprint network-advancing the science of sustainability. http://data.footprintnetwork.org/\#/exploreData. Accessed 11 November 2020.

Glytsos NP (2005) The contribution of remittances to growth. J Econ Stud 32:468-496. https://doi.org/10.1108/01443580510631379

Gök A (2020) The role of financial development on carbon emissions: a meta regression analysis. Environ Sci Pollut Res 27(11):11618 11636. 1-19. https://doi.org/10.1007/s11356-020-07641-7

Grossman GM, Krueger AB (1991) Environmental impacts of a North American free trade agreement (no. w3914). Natl Bur Econ Res. https://doi.org/10.3386/w3914

Gu G, Wang Z (2018) Research on global carbon abatement driven by R\&D investment in the context of INDCs. Energy 148:662-675. https://doi.org/10.1016/j.energy.2018.01.142

Hassan ST, Xia E, Khan NH, Shah SMA (2019) Economic growth, 1143 natural resources, and ecological footprints: evidence from 1144 Pakistan. Environ Sci Pollut Res 26(3):2929-2938. https://doi.org/ 10.1007/s11356-018-3803-3

Ibrahiem DM (2020) Do technological innovations and financial development improve environmental quality in Egypt? Environ Sci Pollut Res 27:10869-10881. 1-13. https://doi.org/10.1007/s11356-01907585-7

Irons, R., \& Irons, R. (2019). Financial markets and institutions. In The fundamental principles of finance https://doi.org/10.4324/ 9780429294976-12

Jiang C, Ma X (2019) The impact of financial development on carbon emissions: A Global Perspective. Sustainability 11(19):5241. https://doi.org/10.3390/su11195241

Jin L, Duan K, Tang X (2018) What is the relationship between technological innovation and energy consumption? Empirical analysis based on provincial panel data from China. Sustainability 10(1): 145. https://doi.org/10.3390/su10010145

Kassouri Y, Altıntaș H (2020) Human well-being versus ecological footprint in MENA countries: A trade-off? J Environ Manag 263: 110405. https://doi.org/10.1016/j.jenvman.2020.110405

Katircioglu S, Gokmenoglu KK, Eren BM (2018) Testing the role of tourism development in ecological footprint quality: evidence from top 10 tourist destinations. Environ Sci Pollut Res 25(33):3361133619. https://doi.org/10.1007/s11356-018-3324-0

Ke H, Yang W, Liu X, Fan F (2020) Does innovation efficiency suppress the ecological footprint? Empirical evidence from 280 Chinese cities. Int J Environ Res Public Health 17(18):6826. https://doi.org/10. 3390/ijerph17186826

Khalid K, Usman M, \& Mehdi MA (2020). The determinants of environmental quality in the SAARC region: a spatial heterogeneous panel data approach. Environ Sci Pollut Res, 1-15.https://doi.org/10.1007/ s11356-020-10896-9

Khan ZU, Ahmad M, \& Khan A (2020). On the remittances-environment led hypothesis: empirical evidence from BRICS economies. Environ Sci Pollut Res 1-12.https://doi.org/10.1007/s11356-02007999-8

Khoshnevis Yazdi S, Ghorchi Beygi E (2018) The dynamic impact of renewable energy consumption and financial development on $\mathrm{CO} 2$ emissions: for selected African countries. Energy Sources Part B: Economics, Planning, and Policy 13(1):13-20. https://doi.org/10. 1080/15567249.2017.1377319

Kirikkaleli D, Adebayo TS, Khan Z, Ali S (2020) Does globalization matter for ecological footprint in Turkey? Evidence from dual 
adjustment approach. Environ Sci Pollut Res 27(1):1087-1100. 1-9. https://doi.org/10.1007/s11356-020-11654-7

Kivyiro P, Arminen H (2014) Carbon dioxide emissions, energy consumption, economic growth, and foreign direct investment: causality analysis for Sub-Saharan Africa. Energy 74:595-606. https://doi. org/10.1016/j.energy.2014.07.025

Kumail T, Ali W, Sadiq F, Wu D, Aburumman A (2020) Dynamic linkages between tourism, technology and $\mathrm{CO} 2$ emissions in Pakistan. Anatolia 31:1-13. https://doi.org/10.1080/13032917.2020.1742169

Kverndokk S, Rosendahl KE, Rutherford TF (2004) Climate policies and induced technological change: which to choose, the carrot or the stick? Environ Resour Econ 27(1):21-41. https://doi.org/10.1023/ B:EARE.0000016787.53575.39

Lin X, Zhang Y, Zou C, Peng L (2020) CO2 emission characteristics and reduction responsibility of industrial subsectors in China. Sci Total Environ 699:134386. https://doi.org/10.1016/j.scitotenv.2019. 134386

Liu H, Kim H, Liang S, Kwon OS (2018) Export diversification and ecological footprint: a comparative study on EKC theory among Korea, Japan, and China. Sustainability 10(10):3657. https://doi. org/10.3390/su10103657

Lu WC (2018) The impacts of information and communication technology, energy consumption, financial development, and economic growth on carbon dioxide emissions in 12 Asian countries. Mitig Adapt Strateg Glob Chang 23(8):1351-1365. https://doi.org/10. 1007/s11027-018-9787-y

Mahmood H, Alkhateeb TTY, Furqan M (2020) Industrialization, urbanization and $\mathrm{CO} 2$ emissions in Saudi Arabia: asymmetry analysis. Energy Rep 6:1553-1560. https://doi.org/10.1016/j.egyr.2020.06. 004

Meyer D, Shera A (2017) The impact of remittances on economic growth: an econometric model. EconomiA 18(2):147-155. https://doi.org/ 10.1016/j.econ.2016.06.001

Mikayilov JI, Mukhtarov S, Mammadov J, Azizov M (2019) Reevaluating the environmental impacts of tourism: does EKC exist? Environ Sci Pollut Res 26(19):19389-19402. https://doi.org/10. 1007/s11356-019-05269-w

Mrabet Z, AlSamara M, Jarallah SH (2017) The impact of economic development on environmental degradation in Qatar. Environ Ecol Stat 24(1):7-38. https://doi.org/10.1007/s10651-016-0359-6

Neog Y, Yadava AK (2020) Nexus among CO2 emissions, remittances, and financial development: a NARDL approach for India. Environ Sci Pollut Res 27(35):44470-44481. https://doi.org/10.1007/ s11356-020-10198-0

Olayungbo DO, Quadri A (2019) Remittances, financial development and economic growth in sub-Saharan African countries: evidence from a PMG-ARDL approach. Financial Innovation 5(1):9. https:// doi.org/10.1186/s40854-019-0122-8

Omri A, Daly S, Rault C, Chaibi A (2015) Financial development, environmental quality, trade and economic growth: what causes what in MENA countries. Energy Econ 48:242-252. https://doi.org/10. 1016/j.eneco.2015.01.008

Ozcan B, Apergis N, Shahbaz M (2018) A revisit of the environmental Kuznets curve hypothesis for Turkey: new evidence from bootstrap rolling window causality. Environ Sci Pollut Res 25(32):3238132394. https://doi.org/10.1007/s11356-018-3165-x

Ozturk I, Al-Mulali U, Saboori B (2016) Investigating the environmental Kuznets curve hypothesis: the role of tourism and ecological footprint. Environ Sci Pollut Res 23(2):1916-1928. https://doi.org/10. 1007/s11356-015-5447-x

Pata UK (2020) Renewable and non-renewable energy consumption, economic complexity, $\mathrm{CO} 2$ emissions, and ecological footprint in the USA: testing the EKC hypothesis with a structural break. Environ Sci Pollut Res 28:1-16. https://doi.org/10.1007/s11356020-10446-3
Pedroni P (2001) Purchasing power parity tests in cointegrated panels. Rev Econ Stat 83(4):727-731. https://doi.org/10.1162/ 003465301753237803

Pesaran MH (2007) A simple panel unit root test in the presence of crosssection dependence. J Appl Econ 22(2):265-312. https://doi.org/10. 1002/jae.951

Pesaran MH, Ullah A, Yamagata T (2008) A bias-adjusted LM test of error cross-section independence. Econ J 11(1):105-127. https://doi. org/10.1111/j.1368-423X.2007.00227.x

Qingquan J, Khattak SI, Ahmad M, Ping L (2020) A new approach to environmental sustainability: assessing the impact of monetary policy on CO2 emissions in Asian economies. Sustain Dev 28(5): 1331-1346. https://doi.org/10.1002/sd.2087

Rahman ZU, Cai H, \& Ahmad M (2019). A new look at the remittancesFDI-energy-environment nexus in the case of selected Asian nations. Singap Econ Rev 1-19.https://doi.org/10.1142/ S0217590819500176

Sagar AD, Holdren JP (2002) Assessing the global energy innovation system: some key issues. Energy Policy 30(6):465-469. https:// doi.org/10.1016/S0301-4215(01)00117-3

Saidi K, Mbarek MB (2017) The impact of income, trade, urbanization, and financial development on $\mathrm{CO} 2$ emissions in 19 emerging economies. Environ Sci Pollut Res 24(14):12748-12757. https://doi.org/ 10.1007/s11356-016-6303-3

Sbia R, Shahbaz M, Ozturk I (2017) Economic growth, financial development, urbanisation and electricity consumption nexus in UAE. Econ Res-Ekonomska istraživanja 30(1):527-549. https://doi.org/ 10.1080/1331677X.2017.1305792

Shahbaz M, Tiwari AK, Nasir M (2013) The effects of financial development, economic growth, coal consumption and trade openness on CO2 emissions in South Africa. Energy Policy 61:1452-1459. https://doi.org/10.1016/j.enpol.2013.07.006

Shahbaz M, Shahzad SJH, Ahmad N, Alam S (2016) Financial development and environmental quality: the way forward. Energy Policy 98:353-364. https://doi.org/10.1016/j.enpol.2016.09.002

Sharif A, Baris-Tuzemen O, Uzuner G, Ozturk I, Sinha A (2020) Revisiting the role of renewable and non-renewable energy consumption on Turkey's ecological footprint: evidence from Quantile ARDL approach. Sustain Cities Soc 57:102138. https:// doi.org/10.1016/j.scs.2020.102138

Sharma K, Bhattarai B, \& Ahmed S (2019). Aid, growth, remittances and carbon emissions in Nepal. Energy J 40(1). https://doi.org/10.5547/ 01956574.40.1.ksha

Sohag K, Begum RA, Abdullah SMS (2015) Dynamic impact of household consumption on its CO 2 emissions in Malaysia. Environ Dev Sustain 17(5):1031-1043. https://doi.org/10.1007/s10668-0149588-8

Su W, Wang Y, Streimikiene D, Balezentis T, Zhang C (2020) Carbon dioxide emission decomposition along the gradient of economic development: the case of energy sustainability in the G7 and Brazil, Russia, India, China and South Africa. Sustain Dev 28(4): 657-669. https://doi.org/10.1002/sd.2016

Tamazian A, Rao BB (2010) Do economic, financial and institutional developments matter for environmental degradation? Evidence from transitional economies. Energy Econ 32(1):137-145. https://doi.org/ 10.1016/j.eneco.2009.04.004

Tian X, Sarkis J, Geng Y, Bleischwitz R, Qian Y, Xu L, Wu R (2020) Examining the role of BRICS countries at the global economic and environmental resources nexus. J Environ Manag 262:110330. https://doi.org/10.1016/j.jenvman.2020.110330

Töbelmann D, Wendler T (2020) The impact of environmental innovation on carbon dioxide emissions. J Clean Prod 244:118787. https:// doi.org/10.1016/j.jclepro.2019.118787

Tshikala SK, Kostandini G, Fonsah EG (2019) The impact of migration, remittances and public transfers on technology adoption: the case of 
cereal producers in rural Kenya. J Agric Econ 70(2):316-331. https://doi.org/10.1111/1477-9552.12295

Uddin GA, Alam K, Gow J (2016) Does ecological footprint impede economic growth? An empirical analysis based on the environmental Kuznets curve hypothesis. Aust Econ Pap 55(3):301-316. https:// doi.org/10.1111/1467-8454.12061

Ulucak R, Apergis N (2018) Does convergence really matter for the environment? An application based on club convergence and on the ecological footprint concept for the EU countries. Environ Sci Pol 80:21-27. https://doi.org/10.1016/j.envsci.2017.11.002

Ulucak R, Yücel AG, Koçak E (2019) The process of sustainability: from past to present. In: Ozcan B, Ozturk I (eds) Environmental Kuznets curve (EKC). Elsevier, Amsterdam, pp 37-53. https://doi.org/10. 1016/B978-0-12-816797-7.00005-9

Usama AM, Solarin SA, Salahuddin M (2020) The prominence of renewable and non-renewable electricity generation on the environmental Kuznets curve: a case study of Ethiopia. Energy 211:118665. https:// doi.org/10.1016/j.energy.2020.118665

Usman M, \& Hammar N (2020). Dynamic relationship between technological innovations, financial development, renewable energy, and ecological footprint: fresh insights based on the STIRPAT model for Asia Pacific Economic Cooperation countries. Environ Sci Pollut Res 1-18.https://doi.org/10.1007/s11356-020-11640-z

Usman M, Kousar R, Makhdum MSA (2020a) The role of financial development, tourism, and energy utilization in environmental deficit: evidence from 20 highest emitting economies. Environ Sci Pollut Res 27(34):42980-42995. https://doi.org/10.1007/s11356020-10197-1

Usman M, Makhdum MSA, Kousar R (2020b) Does financial inclusion, renewable and non-renewable energy utilization accelerate ecological footprints and economic growth? Fresh evidence from 15 highest emitting countries. Sustain Cities Soc 65:102590. https://doi.org/10. 1016/j.scs.2020.102590

Usman M, Kousar R, Yaseen MR, Makhdum MSA (2020c) An empirical nexus between economic growth, energy utilization, trade policy, and ecological footprint: a continent-wise comparison in uppermiddle-income countries. Environ Sci Pollut Res 27(31):3899539018. 1-24. https://doi.org/10.1007/s11356-020-09772-3

Villanthenkodath MA, \& Mahalik MK (2020). Technological innovation and environmental quality nexus in India: does inward remittance matter? J Public Affairs e2291.https://doi.org/10.1002/pa.2291

Wang S, Li G, Fang C (2018) Urbanization, economic growth, energy consumption, and $\mathrm{CO} 2$ emissions: empirical evidence from countries with different income levels. Renew Sust Energ Rev 81:2144 2159. https://doi.org/10.1016/j.rser.2017.06.025

Wang Z, Rasool Y, Zhang B, Ahmed Z, Wang B (2020) Dynamic linkage among industrialisation, urbanisation, and $\mathrm{CO} 2$ emissions in APEC realms: evidence based on DSUR estimation. Struct Chang Econ Dyn 52:382-389. https://doi.org/10.1016/j.strueco.2019.12.001

Wawrzyniak D, Doryń W (2020) Does the quality of institutions modify the economic growth-carbon dioxide emissions nexus? Evidence from a group of emerging and developing countries. Econ ResEkonomska Istraživanja 33(1):124-144. https://doi.org/10.1080/ 1331677X.2019.1708770

Westerlund J (2007) Testing for error correction in panel data. Oxf Bull Econ Stat 69:709-748. https://doi.org/10.1111/j.1468-0084.2007. 00477.x

Wu H, Xu L, Ren S, Hao Y, Yan G (2020) How do energy consumption and environmental regulation affect carbon emissions in China? New evidence from a dynamic threshold panel model. Res Policy 67:101678. https://doi.org/10.1016/j.resourpol.2020.101678

Yang B, Jahanger A, Khan MA (2020a) Does the inflow of remittances and energy consumption increase $\mathrm{CO} 2$ emissions in the era of globalization? A global perspective. Air Qual Atmos Health 13(11): 1313-1328. https://doi.org/10.1007/s11869-020-00885-9

Yang B, Ali M, Nazir MR, Ullah W, \& Qayyum M (2020b). Financial instability and CO 2 emissions: cross-country evidence. Air Qual Atmos Health 1-10.https://doi.org/10.1007/s11869-020-00809-7

Yang B, Ali M, Hashmi SH, Shabir M (2020c) Income inequality and $\mathrm{CO} 2$ emissions in developing countries: the moderating role of financial instability. Sustainability 12(17):6810. https://doi.org/10. 3390/su12176810

Yongping N (2011) The economic thinking on low carbon economy. Energy Procedia 5:2368-2372. https://doi.org/10.1016/j.egypro. 2011.03.407

Yu Y, Du Y (2019) Impact of technological innovation on CO2 emissions and emissions trend prediction on 'New Normal' economy in China. Atmos Pollut Res 10:152-161. https://doi.org/10.1016/j.apr. 2018.07.005

Zafar MW, Saud S, Hou F (2019) The impact of globalization and financial development on environmental quality: evidence from selected countries in the Organization for Economic Co-operation and Development (OECD). Environ Sci Pollut Res 26(13):1324613262. https://doi.org/10.1007/s11356-019-04761-7

Zaidi SAH, Zafar MW, Shahbaz M, Hou F (2019) Dynamic linkages between globalization, financial development and carbon emissions: evidence from Asia Pacific Economic Cooperation countries. J Clean Prod 228:533-543. https://doi.org/10.1016/j.jclepro.2019. 04.210

Zhao Y, Wang S (2015) The relationship between urbanization, economic growth and energy consumption in China: an econometric perspective analysis. Sustainability 7(5):5609-5627. https://doi.org/10. 3390/su7055609

Zhou H, Sandner PG, Martinelli SL, Block JH (2016) Patents, trademarks, and their complementarity in venture capital funding. Technovation 47:14-22. https://doi.org/10.1016/j.technovation. 2015.11.005

Publisher's note Springer Nature remains neutral with regard to jurisdictional claims in published maps and institutional affiliations. 